\title{
Receptor-mediated tumor targeting based on peptide hormones
}

\author{
Gábor Mezo" ${ }^{\dagger} \&$ Marilena Manea \\ 'Eötuös Loránd University, Research Group of Peptide Chemistry, Hungarian Academy of Sciences, 1117 \\ Budapest, Pázmainy P. stny. I/A, Hungary
}

\begin{abstract}
Importance of the field: Tumor targeting with peptides is based on the discovery that receptors for many regulatory peptides are overexpressed in tumor cells, compared with their expression in normal tissues. Consequently, these peptides and their analogues can be used as carriers/targeting moieties for the preparation of diagnostic and therapeutic agents that have increased selectivity and decreased peripheral toxicity.

Areas covered in this review: Here an overview is given of the most relevant gonadotropin-releasing hormone $(\mathrm{GnRH})$ and somatostatin derivatives, as well as of their applications in cancer diagnosis and therapy. For this purpose, recently published data in these areas (mostly articles published from 2000 to 2009) were reviewed.

What the reader will gain: In contrast to other regulatory peptides that stimulate the tumor growth, GnRH and somatostatin derivatives have inhibitory effect; therefore, they were used primarily for the preparation of various conjugates to be used in targeted chemotherapy, targeted radiotherapy, photodynamic therapy, boron neutron capture therapy and cancer diagnosis. Some of these conjugates have already found clinical applications, whereas others are now in preclinical and clinical trials.

Take home message: Tumor targeting with hormone peptides provides a basis for the development of new diagnostic and therapeutic approaches for cancer.
\end{abstract}

Keywords: cancer diagnosis and therapy, drug delivery systems, gonadotropin-releasing hormone, receptor-mediated tumor targeting, somatostatin

\section{Introduction}

Cancer is a leading cause of death and a major public health problem worldwide. According to the statistics of the World Health Organization, in 2007 cancer accounted for 7.9 million deaths ( $\sim 13 \%$ of all deaths) all over the world. Deaths from cancer worldwide are projected to continue rising, with an estimated 12 million deaths in 2030 [1] if no breakthrough in the therapeutic approaches occurs.

Since the middle of the last century, chemotherapy has been the main procedure for the treatment of advanced or metastatic cancer [2]. However, the application of free anticancer drugs has several drawbacks, such as the lack of selectivity, toxicity to normal cells, fast elimination from the blood circulation, and the acquired or intrinsic multi-drug resistance of cancer cells [3]. In the last two decades, cancer research has turned to a more selective, targeted approach, focused on the development of anticancer therapies with improved efficacy and reduced peripheral toxicity [4]. One of the most promising therapeutic strategies is based on the peptide receptors that are overexpressed in tumor cells, in comparision with their expression in normal tissues $[3.5]$. Many regulatory peptides (e.g., somatostatin, 


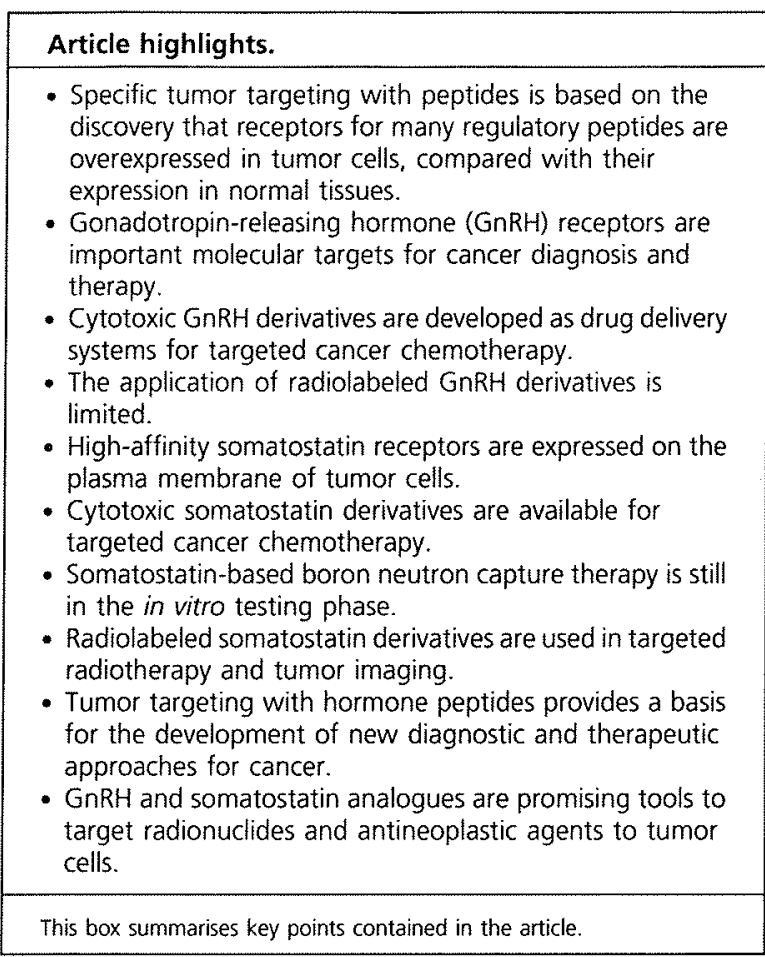

gonadotropin-releasing hormone ( $\mathrm{GnRH})$, bombesin, gastrinreleasing peptide (GRP), neurotensin, substance $P$, vasoactive intenstinal peptide (VIP) and cholecystokinin (CCK)) have membrane-bound receptors on different types of tumor [5]. The receptors recognized by these hormone/neurotransmitter peptides are $\mathrm{G}$-protein-coupled receptors; therefore, they can internalize into the cells after binding of their ligands. Consequently, a cytotoxic agent attached to the peptide can enter the tumor cell by a receptor-mediated way (Figure 1). The advantages of small peptides as carriers are their excellent tissue permeability (except crossing the blood-brain barrier), the lack of immunogenicity, high affinity to the receptors, minimal side effects, rapid clearance from the body, easy synthesis and chemical modifications as well as detailed and precise characterization. The only disadvantage is their rapid proteolytic degradation, which can be partially prevented by insertion of D-amino acids, reduced peptide bonds, $N$-methylor non-native amino acids, and so on. However, it has to be taken into account that regulatory peptides, which control and modulate the function of almost all key organs and metabolic processes, may also play prominent roles in cancer progression. Thus, peptide derivatives (agonists or antagonists) selected for drug delivery should have an inhibitory but not stimulatory effect on tumor growth $[5,6]$. Somatostatin and $\mathrm{GnRH}$ analogues have an inhibitory effect on tumor growth, whereas bombesin, GRP, VIP, CCK, and so on, stimulate it. Considering these aspects, the application of antagonistic derivaties as carriers in the case of the latest ones is suggested by several authors $[5,6]$. However, others prefer agonists (e.g., in the case of bombesin) as drug targeting moieties owing to the observation that agonists induce rapid receptor-ligand internalization by tumor cells, which might be important in the case of targeted cancer chemotherapy $[7,8]$,

Tumor targeting with peptides has found both diagnostic and therapeutic applications. In the case of cancer diagnosis and radiotherapy, a radioligand is usually attached to the regulatory peptide carrier by the aid of a chelator. A wide variety of chelating agents (e.g., diethylenetriaminepentaacetic acid [DTPA] and 1,4,7,10-tetraazacyclododecane1,4,7,10-tetraacetic acid [DOTA]) have been developed for convenient radiolabeling of peptides. Radionuclides such as ${ }^{99 m} \mathrm{Tc},{ }^{111} \mathrm{In},{ }^{68} \mathrm{Ga},{ }^{123} \mathrm{I},{ }^{64} \mathrm{Cu}$ and ${ }^{18} \mathrm{~F}$ can be used for diagnosis and ${ }^{90} \mathrm{Y},{ }^{177} \mathrm{Lu}$ and ${ }^{111} \mathrm{In}$ for therapeutic purposes. Radionuclides used in cancer radiotherapy emit high energy $\beta$-rays or Auger electrons and have longer half-life $(>60 \mathrm{~h})$ in comparision with the $\gamma$-ray or positron emitter radionuclides used as diagnostic tools $[5,9]$.

Another therapeutic application of peptide-based tumor targeting is targeted cancer chemotherapy. In this case, cytotoxic drugs are attached to hormone/neurotransmitter peptides with the aim of increasing their selectivity and decreasing the peripheral toxicity (Figure 1).

The main difference between the conjugates containing radionuclides or drugs is that the antineoplastic agent should be released from the conjugate in order to obtain an efficient tumor growth inhibition, whereas in the case of radiopharmaceuticals this process is not necessary. Therefore, the insertion of $\mathrm{pH}$-sensitive or enzymatic cleavable linkers between the drug and the peptide might be required for the antitumor activity of the cytotoxic conjugates $[10,11]$.

The selection of the peptide to be used as a targeting moiety is based on the type of cancer to be treated. An important aspect of targeted cancer chemotherapy is that the receptor incidence and density must be different on tumoral tissues compared with normal ones. Therefore, VIP peptides seem not to be efficient for drug delivery compared with the others [5].

Here an overview is given of $\mathrm{GnRH}$ and somatostatin analogues that are widely used as carriers for radionuclides and antineoplastic agents.

\section{GnRH receptors as molecular targets for cancer diagnosis and therapy}

Type I and type II GnRH receptors (GnRH-IR and GnRH-IIR) have been identified among vertebrates, including mammals. GnRH-IR protein consists of 329 amino acids and it has no C-terminal cytoplasmic tail [12]. Therefore, GnRH-IRs do not desensitize rapidly and they internalize slowly [13]. The full-length GnRH-IIR have been found in marmoset and rhesus monkeys but not in humans $[14,15]$. The 
A.

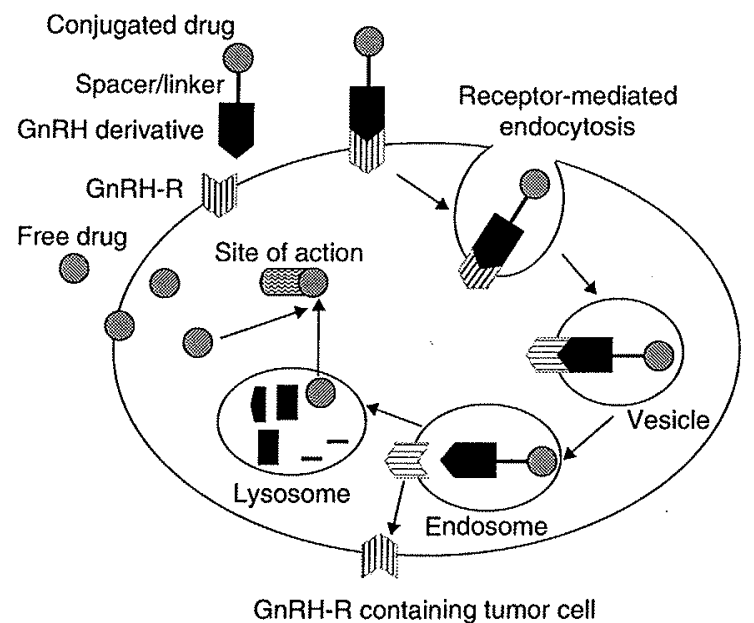

B.

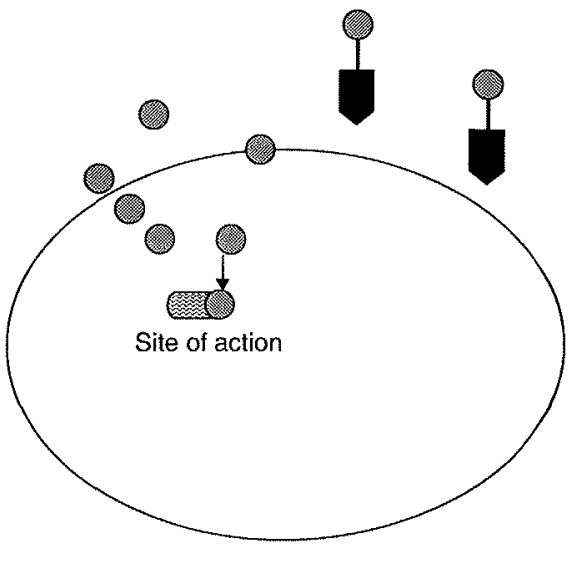

Normal cell without GnRH-R

Figure 1. Cellular uptake of a free and conjugated drug into GnRH-receptor containing tumor cells (A) and into normal cells without GnRH receptors (B).

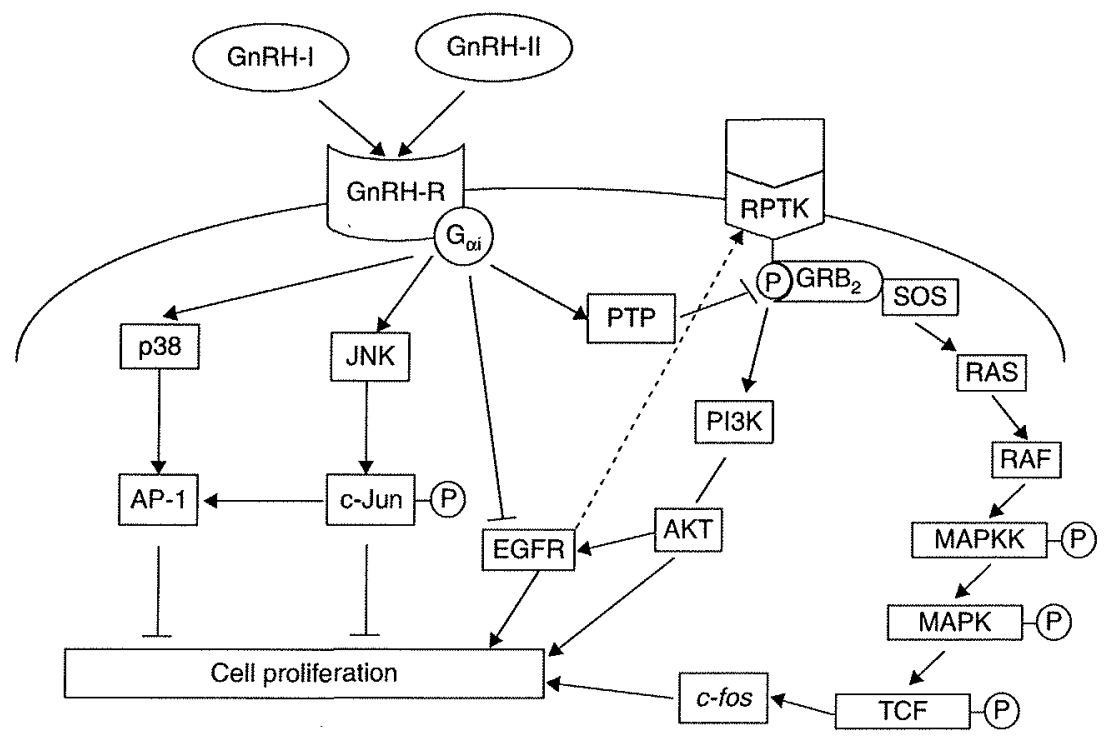

Figure 2. Schematic representation of signaling pathways of GnRH-I,II in cancer cells.

AP-1: Activator protein-1; EGFR: Epidermal growth factor receptor; $G_{a i}$ G-protein oi; GRB2: Growth factor receptor bound protein; JNK: c-Jun N-terminal kinase; MAPK: Mitogen-activated protein kinase; MAPKK: MAPK kinase; PISK: Phosphoinositide 3 kinase; PTP: Phosphotyrosine phosphatase; RPTK: Receptor protein tyrosine kinase; SOS: Son of Sevenless; TCP: Transcription factor.

GnRH-IIR has a cytoplasmic tail and undergoes rapid arrestin-dependent internalization and desensitization [16]. The mRNA expression of this full-length GnRH-IIR has also been shown by real-time polymerase chain reaction (RT-PCR) in human cancer cell lines [17]. However, it became evident that GnRH-IIRs have a frameshift and a premature stop codon and thus they are not functional. Therefore, it is believed that the GnRH-II signaling might also occur through the GnRH-IR (Figure 2) [18]. By contrast, after knockout of GnRH-IR expression in endometrial and ovarian cancer cells, the antiproliferative effect of $\mathrm{GnRH}$ agonist Triptorelin ([D-Trp $]-G n R H)$ was abrogated, whereas the tumor growth-inhibitory effect of GnRH-II persisted [19]. Recent data of extensive research have shown that functional GnRH-IIR might occur on human cancer cells [20]. However, an intensive study of the role of GnRH-IIRs on tumor cells 
Table 1. In vivo and in vitro antitumor effect of $\mathrm{AN}-152$ and $\mathrm{AN}-207$ conjugates.

\begin{tabular}{|c|c|c|c|c|}
\hline Tumor type & $\begin{array}{l}\text { Receptor expression } \\
\text { in specimens }\end{array}$ & $\begin{array}{l}\text { Cell types that } \\
\text { express GnRH-R }\end{array}$ & AN-152 & AN-207 \\
\hline Breast & $>50$ & $\begin{array}{l}\text { MCF-7 } \\
\text { MDA-MB-231 } \\
\text { MDA-MB-435 } \\
\text { MX-1 } \\
\text { T47-D } \\
\text { HCC-70 } \\
\text { ZR-75-1 } \\
\text { MXT (mouse) }\end{array}$ & $\begin{array}{l}\text { AN-152>Dox* } \\
\text { n.d. } \\
\text { n.d. } \\
X X X \\
\text { AN-152>Dox } \\
\text { AN-152 > Dox } \\
\text { AN-152<Dox } \\
X X X X\end{array}$ & $\begin{array}{l}\text { AN-207 > Dox } \\
X X X X^{\ddagger} \\
X X X \\
X X X X X \\
\text { n.d. } \\
\text { n.d. } \\
\text { n.d. } \\
X X X X\end{array}$ \\
\hline Ovarian & $>70$ & $\begin{array}{l}\text { OV-1063 OVCAR-3 } \\
\text { ES-2 } \\
\text { EFO-21 } \\
\text { EFO-27 }\end{array}$ & $\begin{array}{l}X X X X \\
X X X X X \\
X X \\
\text { AN-152>DoX } \\
\text { AN-152<DoX }\end{array}$ & $\begin{array}{l}x x x \\
\text { n.d. } \\
x x x \\
\text { n.d. } \\
\text { n.d. }\end{array}$ \\
\hline Endometrial & $>75$ & $\begin{array}{l}\text { Ishikawa } \\
\text { HEC-1A } \\
\text { HEC-1B } \\
\text { RC-95-2 }\end{array}$ & $\begin{array}{l}\text { AN-152>DoX } \\
X X X \\
X X X X X \\
\text { n.d. }\end{array}$ & $\begin{array}{l}\text { n.d. } \\
x x x \\
\text { n.d. } \\
x x x\end{array}$ \\
\hline Prostate & $>85$ & $\begin{array}{l}\text { LNCaP } \\
\text { MDA-PCa-26 } \\
\text { MDA-PCa-2b } \\
\text { DU-145 } \\
\text { C4-2 } \\
\text { PC-82 } \\
\text { LuCaP-35 } \\
\text { R-3327-H (rat) } \\
\text { R-3327-AT-1 (rat) }\end{array}$ & $\begin{array}{l}X X X X \\
X X X \\
X X X \\
\text { n.d. } \\
X X X(P S A \text { inh.) } \\
\text { n.d. } \\
\text { n.d. } \\
X X X \\
X X\end{array}$ & $\begin{array}{l}\text { n.d. } \\
\text { n.d. } \\
X X X \\
X X X X \\
\text { n.d. } \\
X X X \\
X X X X \\
X X X \\
\text { n.d. }\end{array}$ \\
\hline Colon & n.d. & $\begin{array}{l}\text { HT-29 } \\
\text { HCT-116 } \\
\text { HCT-15 } \\
\text { LoVo } \\
\text { Colo-320DM }\end{array}$ & $\begin{array}{l}X X \\
X \\
X X X X \\
X X X \\
X X X X\end{array}$ & $\begin{array}{l}X X X \\
X X X \\
X X X X \\
X X X \\
X X\end{array}$ \\
\hline Renal & 80 & $\begin{array}{l}\text { A-498 } \\
\text { ACHN } \\
786-0\end{array}$ & $\begin{array}{l}\text { n.d. } \\
\text { n.d. } \\
\text { n.d. }\end{array}$ & $\begin{array}{l}X X X X \\
X X X X \\
X X X\end{array}$ \\
\hline Melanoma & 100 & $\begin{array}{l}\text { MRI-H255 } \\
\text { MRI-H187 }\end{array}$ & $\begin{array}{l}\text { n.d. } \\
\text { n.d. }\end{array}$ & $\begin{array}{l}X X X X \\
X X X\end{array}$ \\
\hline Lung & n.d. & $\mathrm{NCl}-\mathrm{H} 72 \mathrm{O}$ & AN-152 > Dox & n.d. \\
\hline Non-Hodgkin's lymphoma & 100 & $\begin{array}{l}\text { RL } \\
\text { HT }\end{array}$ & $\begin{array}{l}\text { n.d. } \\
\text { n.d. }\end{array}$ & $\begin{array}{l}X X X X \\
X X X X\end{array}$ \\
\hline Hepatocellular & n.d. & SK-Hep-1 & n.d. & $x X X X$ \\
\hline Oral & n.d. & $\mathrm{KB}$ & AN-152 > Dox & n.d. \\
\hline Laryngeal & n.d. & HEp-2 & AN-152> Dox & n.d. \\
\hline
\end{tabular}

${ }^{*} \mathrm{AN}-152>$ Dox represents the comparison of the in vitro antitumor effect of free drug and its GnRH derivative conjugate.

In vivo studies: XXXXX: regression; XXXX: > 70\% inhibition; XXX: $50-70 \%$ inhibition; XX: $25-50 \%$ inhibition; n.d.: not determined.

\$PSA inh.: not the tumor volume, but PSA level was determined as a measure of the inhibitory effect.

The effects are not absolutely comparable because of different doses and treatment schedules used.

and of the mechanism of action of GnRH-II should be carried out. In addition to GnRH-IR, GnRH-IIR might be a good target for tumor therapy.

GnRH-R expression was identified on different tumors (breast, ovarian, endometrial, prostate, renal, brain, pancreatic, melanomas, non-Hodgkin's lymphomas, etc.) (Table 1) [21-23]. The limited number of GnRH-Rs in normal tissues provided a basis for the development of diagnostic and therapeutic approaches of cancer (Figure 1).

\section{Cytotoxic GnRH derivatives}

Cytotoxic GnRH derivatives were initially developed by Schally's group after the mid-1980s. The first series of 
conjugates contained agonistic (e.g., [D-Lys ${ }^{6}$ ]-GnRH; GlpHis-Trp-Ser-Tyr-D-Lys-Leu-Arg-Pro-Gly-NH $\mathrm{NH}_{2}$ or antagonistic (e.g., $\left[\mathrm{Ac}-\mathrm{D}-\mathrm{Nal}(2)^{1}, \mathrm{D}-\mathrm{Phe}(\mathrm{pCl})^{2}, \mathrm{D}-\mathrm{Pal}^{3}, \mathrm{Arg}^{5}, \mathrm{D}-\mathrm{Lys}^{6}\right.$, $\mathrm{D}-\mathrm{Ala}^{10}{ }^{10}$-GnRH) $\mathrm{GnRH}$ derivatives as carriets and cytotoxic moieties such as alkylating agents cisplatin and melphalane, antimetabolite methotrexate, DNA intercalating agents doxorubicin (Dox) and (2-hydroxymethyl)anthraquinone $[21,24,25]$. Based on the results of in vitro and in vivo studies using these compounds, more efficient conjugates were developed in which Dox or its analogue (2-pyrrolino-Dox; AN-201, which is $500-1000$ times more potent than Dox) were attached to [D-Lys']-GnRH [26]. In these compounds AN-152 (1) (Figure 3A) and AN-207 (2) (Figure 3B), the cytotoxic agents connected to glutaric acid by means of an ester bond (Dox-14-O-hemiglutarate), were conjugated to the $\varepsilon$-amino group of D-Lys ${ }^{6}$ of GnRH. The ester bond could be cleaved by carboxylesterases (CE), leading to the release of the free cytotoxic radicals. Cellular uptake studies showed that the conjugates were internalized in a receptor-mediated way by GnRH-R-positive cells (Figure 1A) but not by GnRH-Rnegative cells (Figure $1 \mathrm{~B}$ ). The receptor-mediated internalization was also confimed by blocking the receptors with the superagonist Triptorelin [27].

The antitumor action of AN-152 and AN-207 was studied intensively on numeouros tumor types (Table 1). Their efficiency was tumor type-dependent, but in almost all cases AN207 had higher antitumor activity. Significant in vivo tumor growth inhibition and the regression of several tumor types (e.g., ovarian, endometrial, breast and prostate cancers) were observed. These results have been reviewed extensively $[3,21,28,29]$. In the last few years, the strong inhibitory activity of the conjugates has been shown on more tumor types, such as renal, non-Hodgkin's lymphomas, melanomas, colorectal and hepatocellular carcinoma cell lines that expressed GnRH-Rs [22,23,30-32]. In most cases, the intravenous-administered conjugates were far less toxic and inhibited the growth of GnRH receptor-positive tumors better than the equimolar doses of free doxorubicin. Furthermore, AN-152 induces apoptosis in GnRH receptor-positive human ovarian and endometrial cancer cell lines without activating the MDR-1 (multi-drug resistance-1) efflux pump system [33].

Although the tumor growth inhibition effect of AN-207 was higher, AN-152 was the first cytotoxic $\mathrm{GnRH}$ derivative investigated in preclinical and clinical studies. In the Phase I clinical trial for ovarian and endometrial cancers (Eterna Zentaris, AEZS-108), AN-152 was well tolerated using escalated doses of 160 and $267 \mathrm{mg} / \mathrm{m}^{2}$. Even at the highest dose, the hematological toxicity of AN-152 was low and the other non-hematological side effects were mild [34]. The Phase II clinical trial started in January 2008.

It is worth mentioning that the side effects of the conjugates were mainly related to the easy drug release by $C E$. In an early study, it was demonstrated that the half-life of $\mathrm{AN}-152$ in mouse serum was $-20 \mathrm{~min}$, whereas in human serum it lasted a longer time, with a half-life of $2 \mathrm{~h}$ [35]. This difference could be explained by the CE levels in mouse and human sera (the $\mathrm{CE}$ level in mouse serum is $\sim 10$ times higher than in human serum). Therefore, to reduce the toxicity of the conjugate in many in vivo experiments, diisopropyl-fluorophosphate was used as a CE inhibitor. In this way the half-life of $A N-152$ in mouse serum was enhanced to $\sim 70 \mathrm{~min}$ and the maximal tolerated dose (MTD) was increased from 200 to $2 \times 400 \mathrm{nM}$. The hydrolyzed Dox and especially 2-pyrrolino-Dox had a non-receptor specific cytotoxic effect on rapidly proliferating cells, the main toxic side effect being the myelotoxicity. Another side effect might originate from the presence of GnRH-Rs on normal reproductive cells and gonadotroph cells. The temporary damage of gonadotrophs using AN-207 was recovered $\sim 1$ week after cessation of the treatment [36]. In the case of hormone-dependent tumors patients are usually hypophysectomized, thus this side effect of the cytotoxic GnRH derivatives is not harmful [37].

A natural isoform of GnRH, GnRH-III (Glp-His-Trp-SerHis-Asp-Trp-Lys-Pro-Gly- $\mathrm{NH}_{2}$ ), which is a weak GnRH agonist, has recently been used as a carrier in the authors' laboratories. This hormone peptide, isolated from sea lamprey (Petromyzon marinus) [38], specifically binds to the GnRH-Rs on cancer cells [39]. GnRH-III has antiproliferative activity on several tumor cell lines and 500-1000 times less potency in LH and FSH secretion both in vitro and in vivo, indicating its selective antitumor activity [40]. The modification of the side chain of Lys ${ }^{8}$ did not result in the loss of the antiproliferative activity of GnRH-III [41]. Furthermore, the absence of the free $\varepsilon$-amino group of lysine decreased the endocrine effect of the compounds [42]. Therefore, $\mathrm{Lys}^{8}$ might be used as a conjugation site for the attachment of cytotoxic drugs. Daunorubicin (Dau), an anthracycline derivative that differs from doxorubicin in the substitution at the C-14-position ( $\mathrm{H}$ instead of $\mathrm{OH}$ ) and has lower cardiotoxicity than Dox, was conjugated to GnRH-III via oxime (3) (Figure 3C) or hydrazone (4) bonds (Figure 3D). As the oxime bond is relatively stable under physiological conditions, a GFLG tetrapeptide spacer known to be cleaved by lysosomal enzymes, especially by Cathepsin B which is overexpressed in tumor cells $[41,43,44]$, was inserted between the drug and the hormone peptide. Ester bond-containing Dox-GnRH-III conjugates were also prepared. In vitro cytostatic effect of the conjugates was determined by MTT assay on MCF-7 human breast cancer and HT-29 human and C26 murine colon carcinoma cell lines [25,41]. The results were compared with the $\mathrm{IC}_{50}$ values of the free drugs and AN-152. All compounds were more potent on breast cancer cell lines; however, there were no significant differences between their antitumor effects on colon cancer cells. The ester bond-containing conjugates had similar antitumor activity as the free drugs and one order of magnitude higher activity than that of the conjugates containing hydrazone or oxime bonds.

The in vivo toxicity study on BDF-1 mice indicated high tolerability of oximebond-linked GnRH-III(Dau=Aoa-GFLG) conjugate. This conjugate had an MTD > $54 \mu \mathrm{mol}$ 
A.

Glp-His-Trp-Ser-Tyr-D-Lys-Leu-Arg-Pro-Gly-NH ${ }_{2}$

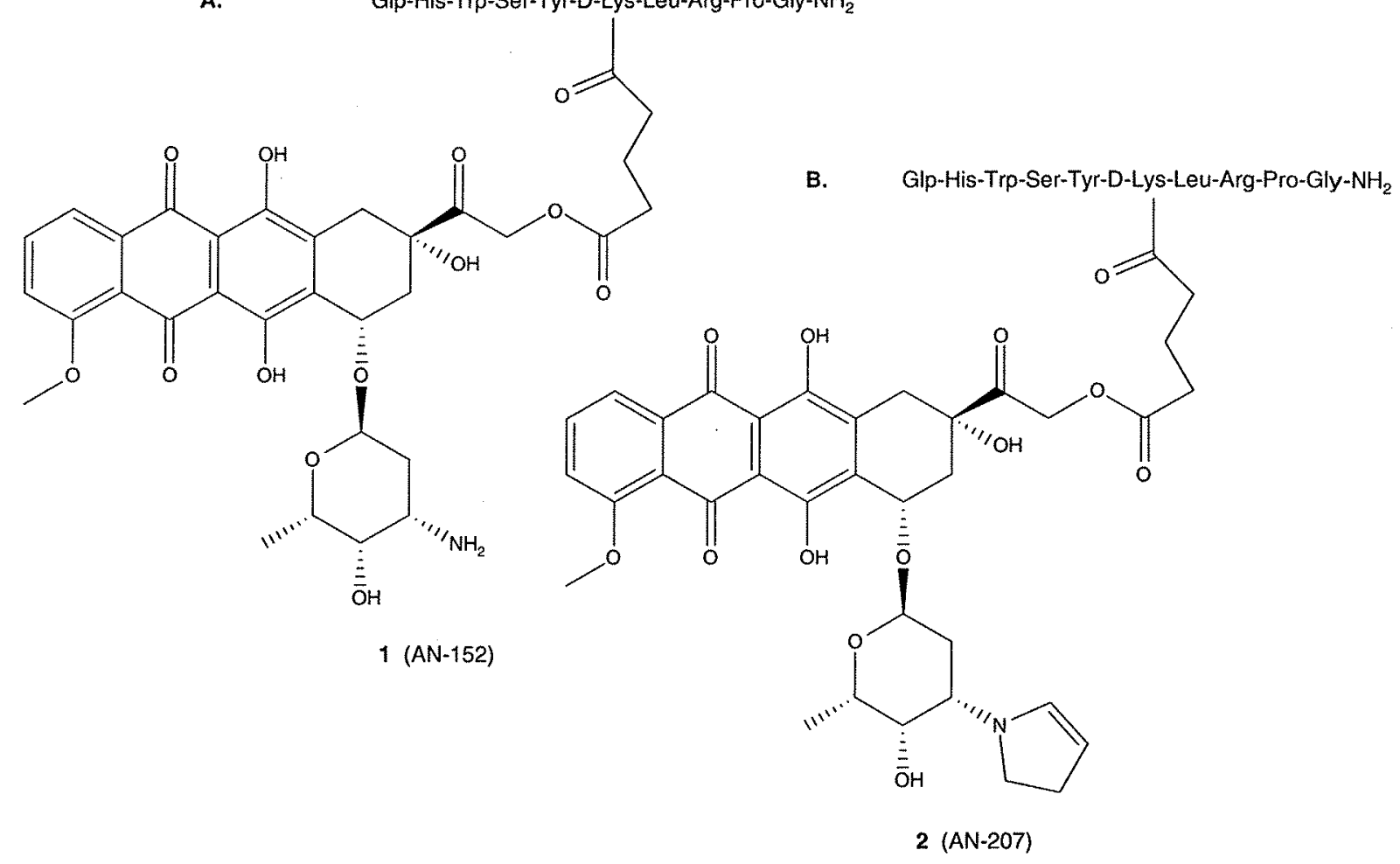

C. Glp-His-Trp-Ser-His-Asp-Trp-Lys-Pro-Gly- $\mathrm{NH}_{2}$

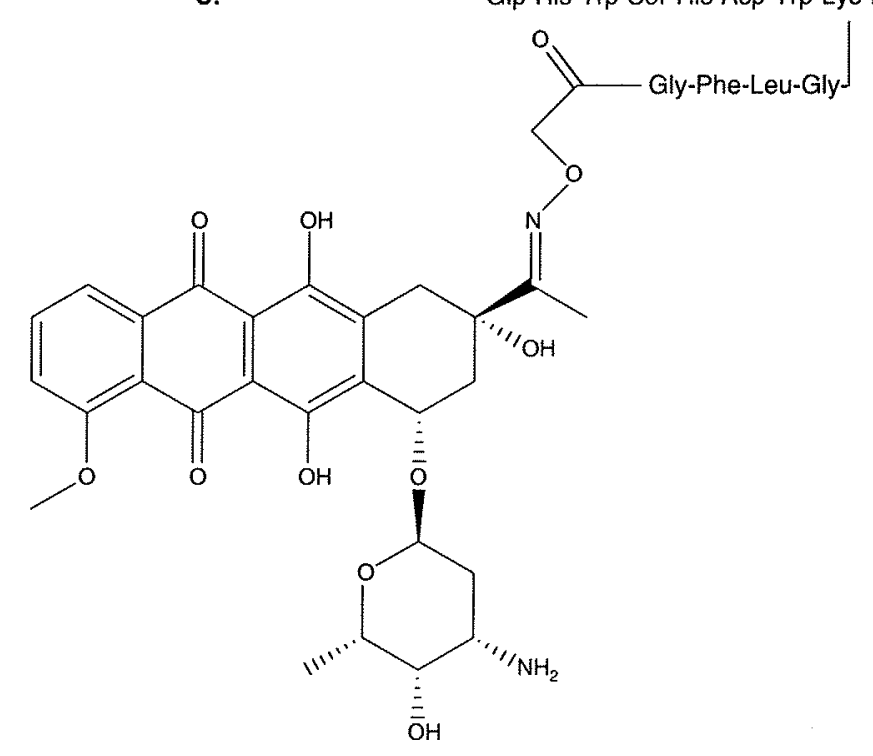

3

Figure 3. Chemical structures of cytotoxic GnRH derivatives: ester bond-linked doxorubicin-[D-Lys ${ }^{6}$ ]-Gn RH (A) and 2-pyrrolinodoxorubicin-[D-Lys ${ }^{6}$ ]-GnRH (B), oxime bond containing daunorubicin-GnRH-III (C), hydrazone bond-linked daunorubicin$\mathrm{GnRH}-\mathrm{III}(\mathrm{D})$ and of a radiolabeled GnRH derivative, $\mathrm{D}-\mathrm{Lys}^{6}\left(\mathrm{Ahx}-\left[^{18} \mathrm{~F}\right] \mathrm{FBOA}\right)-\mathrm{GnRH}(\mathrm{E})$.

Ahx: $\varepsilon$-Aminohexanoic acid; FBOA: p-Fluorobenzyloxime acetyl. 


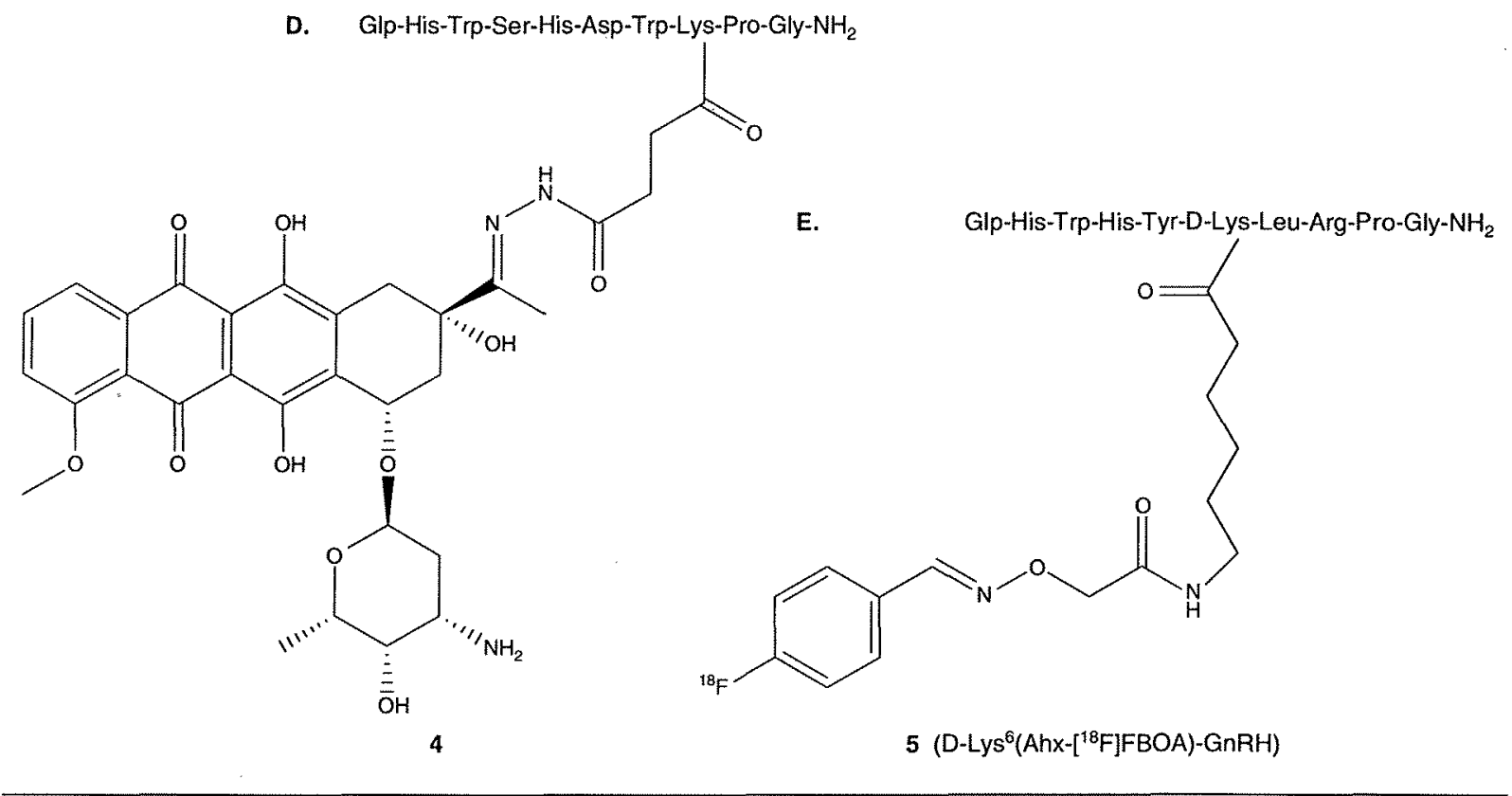

Figure 3. Chemical structures of cytotoxic GnRH derivatives: ester bond-linked doxorubicin-[D-Lys ${ }^{6}$ ]-Gn RH (A) and 2-pyrrolinodoxorubicin-[D-Lys $\left.{ }^{6}\right]-G n R H(B)$, oxime bond containing daunorubicin-GnRH-III (C), hydrazone bond-linked daunorubicinGnRH-III (D) and of a radiolabeled GnRH derivative, D-Lys ${ }^{6}\left(A h x-\left[{ }^{18} \mathrm{~F}\right] \mathrm{FBOA}\right)$-GnRH (E). (Continued)

Ahx: $\varepsilon$-Aminohexanoic acid; FBOA: $p$-Fluorobenzyloxime acetyl.

Dau-content in the conjugate per kilogram using intraperitoneal administration. The in vivo antitumor activity of the conjugate was evaluated on $\mathrm{C} 26$ colon cancer-bearing mice and the tumor growth inhibition was $20-46 \%$ depending on the dose and on the time schedule. Similar results were obtained after the administration of the free Dau. However, the survival of the animals treated with the conjugate increased by $15-40 \%$ compared to the controls, whereas the animals treated with the free drugs died earlier [41].

Rahimipour et al. applied [D-Lys ${ }^{6}$ ]-GnRH and [D-Glp ${ }^{1}, \mathrm{D}-$ $\left.\mathrm{Phe}^{2}, \mathrm{D}-\mathrm{Trp}^{3}, \mathrm{D}-\mathrm{Lys}^{6}\right]-\mathrm{GnRH}$ (an antagonistic peptide) to increase the selectivity of protoporphyrin IX (PpIX) as a photosensitizer for photodinamic therapy [45]. In both cases, PpIX was conjugated to D-Lys ${ }^{6}$ by means of amide bonds. The conjugates bound to the GnRH-Rs with lower affinity than the parent peptides, but their selective and efficient phototoxicity compared with the unconjugated PpIX could be demonstrated.

Drug delivery systems based on GnRH targeting moieties were developed by Dharap et al. Camptothecin (CPT) was connected to Glp-His-Trp-Ser-Tyr-D-Lys-Leu-Arg-Pro-EA (EA: ethylamide) through a polyethylene glycol (PEG) chain. CPT was attached to the cysteine by means of an ester bond and then Cys-CPT was conjugated to NHS-PEG-VS (NHS: $N$-hydroxysuccinimide; VS: vinylsulfone) by a thioether bond. After that, the GnRH derivative was attached to the PEG conjugate by means of an amide bond. PEG increased the solubility and bioavailibility of the conjugate. The
GnRH-PEG-CPT conjugate showed higher cytotoxicity and apoptosis induction than the free CPT or PEGCPT [46]. These results indicated the efficiency of receptormediated endocytosis for selective drug targeting over the simple diffusion or direct endocytosis [47]. Moreover, in vivo experiments did not show any disturbance of the reproductive functions of female mice. GnRH-PEG-CPT conjugate accumulated in tumor cells but, similarly to the free CPT and PEG-CPT, caused overexpression of $B C L-2$ and $B C L-X L$ genes and thereby increased the cellular antiapoptotic defense. To overcome this drawback, a multifunctional targeted proapoptotic drug delivery system was designed. This new conjugate contained a $\mathrm{BH} 3$ antiapoptotic peptide (MGQVGRQLAIIGDDINRRY) beside the GnRH derivative, CPT and PEG. The conjugation of the three components to $P E G$ was performed by inserting a multifunctional citric acid spacer that allowed simultaneous binding of several copies of different active components to one polymeric carrier [48,49]. It is important to note that $\mathrm{BH} 3$ peptide could not enter the cells without any targeting moiety [50]. The conjugate containing all four components induced the greatest supression of the antiapoptotic gene expression and the highest cytotoxic and apoptotic effects in A2780 human ovarian carcinoma cell line as compared with the conjugates CPT-PEG-BH3 and GnRH-PEG-CPT or their physical mixture. The conjugate also showed antitumor activity on A2780/AD multi-drug resistant human ovarian carcinoma cell line, but the effect was lower than in case of non-resistant cell lines. 


\section{Radiolabeled GnRH derivatives}

Except radioiodinated compounds, only a few data have been published so far about the development of other radiolabeled $\mathrm{GnRH}$ derivatives. Barda et al. prepared a ${ }^{99 \mathrm{~m}} \mathrm{Tc}$-labeled GnRH derivative as a potential single photon emission computed tomography (SPECT) tracer [51]. However, the insertion of the radiometal via backbone cyclization of the peptide led to a dramaric loss of the binding affinity. Schotrelius et al. investigated ${ }^{68} \mathrm{Ga}$ - and ${ }^{18} \mathrm{~F}$-labeled $\mathrm{GnRH}$ analogues [52]. Ga was incorporated by the aid of DOTA, while for the insertion of $F$, $p$-fluorobenzyloxime aceryl (FBOA) moiety was applied. DOTA was attached directly to the $\varepsilon$-amino group of D-Lys in [D-Lys ${ }^{6}$-GnRH, whereas in case of the fluor-containing derivative, either $\beta$-alanine or $\varepsilon$-aminohexanoic acid (Ahx) were inserted between the peptide and the radioligand. In the in vitro binding experiments, radioiodinated Triptorelin ( ${ }^{125}$ I-[D-Trp $\left.{ }^{6}\right]-\mathrm{GnRH}$ ) was also used. The compound radiolabeled with ${ }^{68} \mathrm{Ga}$ had very low binding capacity, whereas the binding of fluorinated derivatives was four to six times lower than the radiolabeled Triptorelin. Compared with Triptorelin, the internalization of $\mathrm{D}-\mathrm{Lys}^{6}\left(\mathrm{Ahx}-\left[{ }^{18} \mathrm{~F}\right] \mathrm{FBOA}\right)-\mathrm{GnRH}$ (5) (Figure 3E) into EFO-27 ovarian carcinoma cells was $86 \pm 16 \%$, whereas the $\beta$-Ala-derivative showed only $42 \pm 3 \%$. There was no significant internalization observed in case of the Ga-labeled GnRH derivative. These data suggested that the lipophilicity of the compound that modified the lysine side chain and the distance between the peptide backbone and the radiolabeled moiety had significant influence on the binding capacity of the conjugate to the receptor and on its internalization properties. However, the biodistribution of the conjugates in OVCAR-3 ovarian tumor-bearing mice indicated no significant tumor localization $(-0.5 \%)$ of radiolabeled compounds. The results showed a very low level of GnRH-R expression on tumor cell surfaces, suggesting that the GnRH-R system is not a suitable target for peptide-receptor imaging using radiolabeled GnRH analogues. This is in contrast to the effective tumor growth inhibition by cytotoxic GnRH derivatives. The contradiction might be explained by the observations that GnRH-R protein is inefficiently processed by the cells under physiological conditions and it is retained at the site of production [53]. A proportion of intracellular receptors might traffic to the cell surface during stimulation, thus providing a rationale for the successful application of $\mathrm{GnRH}$ analogues for suppressing the tumor growth [54].

Considering these data, one can conclude that GnRH-Rs represent a highly interesting target for pharmacological interventions; however, many open questions have to be answered in the future.

\section{Somatostatin receptors as molecular targets for cancer diagnosis and therapy}

It has been shown that somatostatin and its analogues can inhibit tumor growth. Their action is mediated by specific, high-affinity somatostatin receptors located on the plasma membrane of the tumor cells. Up to now, five human somatostatin receptor subtypes (sst $1-s s t_{5}$ ) have been cloned and partially characterized [5.9]. The most frequent receptor subtypes on tumor cells are $s_{2} t_{2}$ and sst $_{5}$. On ligand binding, sst $_{3}$ and $s s t_{2}$ internalize more efficiently than $s t_{1}$ or sst $_{5}$. Somatostatin receptors were detected in a low amount in human brain and in many peripheral tissues such as pancreas, gut, thyroid, adrenal and kidney. Therefore, during the application of somatostatin analogues for targeted therapy, the unwanted side effects should be carefully investigated. As both somatostatin-14 and somatostatine-28 bound with high affinity to all receptor subtypes, more selective derivatives to $s t_{2}$ and $s_{5} t_{5}$ were developed for tumor therapy, one of the most efficient compounds being octreotide (OCT, Sandostatin ${ }^{\circledR}$, Sandoz), a cyclic octapeptide alcohol (D-Phe-c(Cys-Phe-D-Trp-Lys-Thr-Cys)-Thr-ol) [55].

\section{Cytotoxic somatostatin derivatives}

In the mid-1980s, similarly to GnRH derivatives, intensive studies of new somatostatin analogues were carried out by Schally's group. An analogue of octreotide (H-D-Phe-c(CysTyr-D-Trp-Lys-Val-Cys)-Thr-NH $\left.\mathrm{NH}_{2}, \quad \mathrm{RC}-121\right) \quad[28,56] \quad$ was found to be efficient, especially for drug targeting. An initial study of a conjugate in which methotrexate was linked to the $\mathrm{N}$ terminus of $\mathrm{RC}-121$ indicated the tolerance of the carrier for the amino terminal modifications. Later on, Dox and pyrrolino-Dox (AN-201) were conjugated to RC-121, resulting in AN-162 (6) (Figure 4A) and AN-238 (7) (Figure 4B) derivatives [57]. The conjugates that fully retained the cytotoxicity of the drugs and the receptor binding affinity of the peptide carrier showed strong growth inhibition of various tumors (Table 2) that express $s t_{2}, s s t_{3}$ and $s t_{5}$ (breast, renal, ovarian, lung, colorectal, pancreatic tumors) $[3,6,58,59]$. AN-238, similarly to the AN-207 GnRH analogue, was very effective intravenously at $\sim 200 \mathrm{nmol} / \mathrm{kg}$ doses corresponding to $0.4-0.45 \mathrm{mg} / \mathrm{kg}$. The estimated human doses would be $-22.5 \mathrm{mg} / 50 \mathrm{~kg}$. In mice, AN-238 showed no or low toxicity up to a dose of $400 \mathrm{nmol} / \mathrm{kg}$. The toxic side effects might be related to the release of $A N-201$ resulting from the cleavage of the ester bond by carboxylesterases. The toxicity occurred mostly on the fast dividing cells, such as gastrointestinal or myeloid cells, resulting in a transient fall in the white blood cell (WBC) count and body weight. As the esterase activity is much lower in humans than in mice, the hematotoxicity of $\mathrm{AN}-238$ is expected to be reduced in patients, as demonstrated in case of the GnRH derivative. In addition, no significant nephrotoxicity was observed under the treatment with AN-238.

In the past few years, it has been shown that AN-238 is efficient on human endometrial carcinomas that have not responded well to chemotherapy [60]. Chemoresistance mediated by membrane transporters, such as multi-drug resistance (MDR-I) glycoprotein, can be avoided by targeted therapy. AN-238 not only induced tumor growth inhibition 


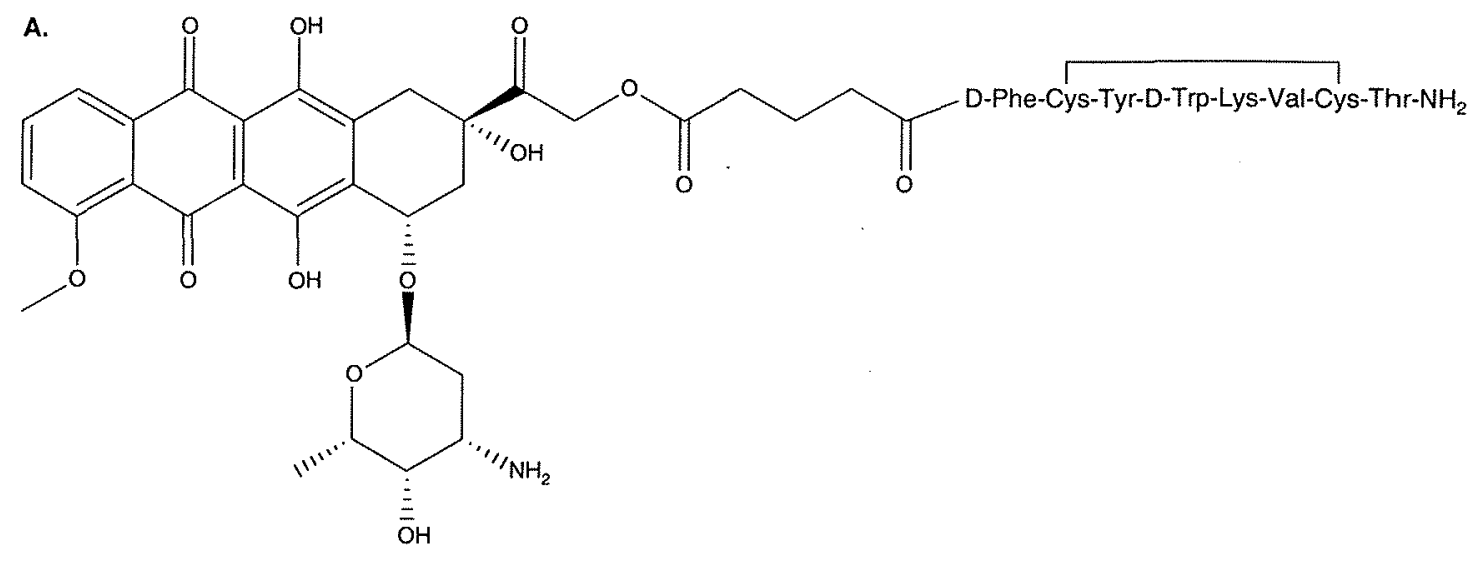

$6(\mathrm{AN}-162)$

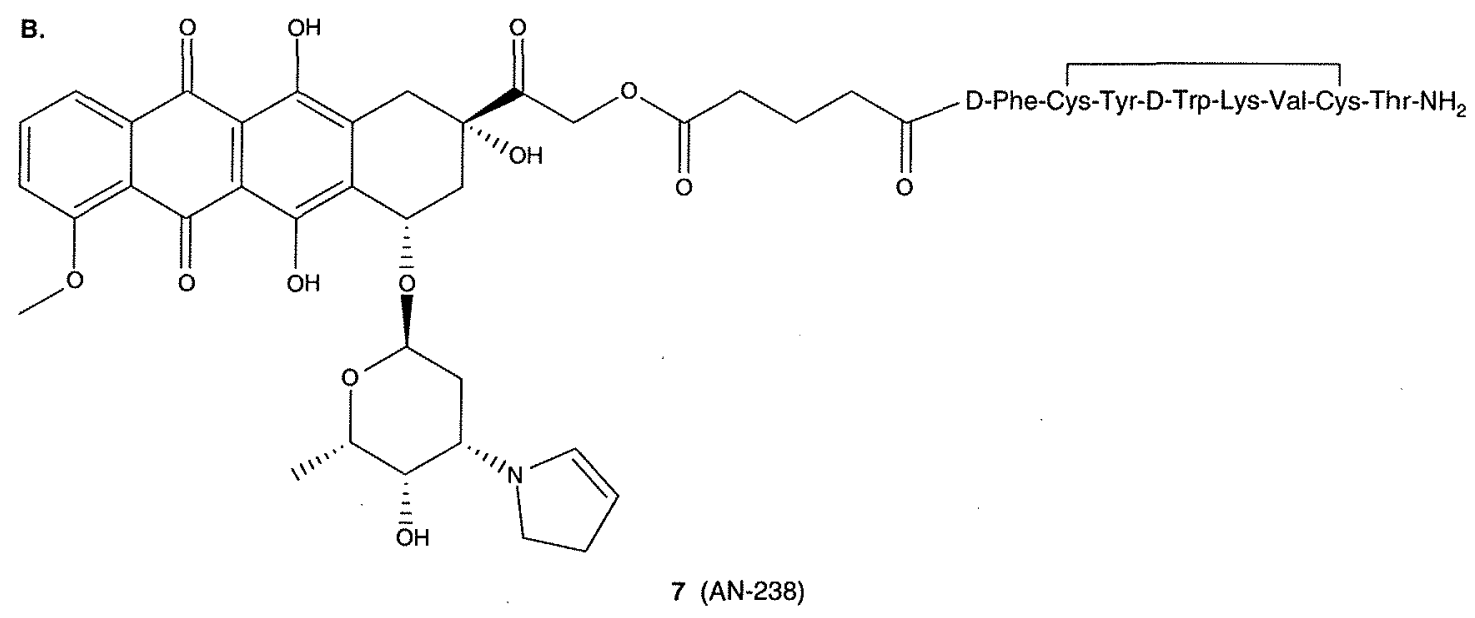

Figure 4. Chemical structures of cytotoxic somatostatin derivatives in which doxorubicin (A) and 2-pyrrolino-doxorubicin (B) were attached via ester bond to an octreotide analogue; ester bond-linked paclitaxel-octreotide (C) and carbamate containing camptothecin-somatostatin derivative conjugate (D).

$(50-65 \%)$ of endometrial carcinomas, but also the expression of MDR-I protein during the treatment was much lower than in case of the treatment with AN-201.

Lung cancer is one of the tumor types that can be treated better by targeted therapy based on somatostatin derivative carriers than by using cytotoxic GnRH derivatives. About $80 \%$ of all lung cancers are classified as non-small cell lung cancer (NSCLC). Therefore, the presence of somatostatin receptors in NSCLCs to a greater extent than in normal cells makes them good targets for cytotoxic somatostatin derivatives [61,62]. AN-238 was found to be effective on H69 (SCLC) and H157, H838 (NSCLCs) [63,64]. However, large-scale synthesis of an AN-238 is still in progress. Therefore, AN-162 (Æterna Zentaris, AEZS-124) was used for preclinical studies, and it has recently been investigated for the inhibition of NSCLCs [65]. All studied NSCLCs (A549, H460, H838 and H1299) expressed $s s t_{1}, s s t_{2}$ and $s t_{4}$. Strong expression of mRNA for sst $_{5}$ was found in A549 and H460 and it was marginal in
H838, whereas sst ${ }_{3}$ was present in $\mathrm{H} 460$ and H1299. A549, $\mathrm{H} 460$ and $\mathrm{H} 1299$ are resistant to doxorubicin, thus AN-162 was more effective than the free drug on proliferation inhibition in vitro. The best results $(17 \%$ cell viability at $50 \mu \mathrm{M})$ were obtained in the case of $\mathrm{H} 460$ cells that express all the receptor subtypes. A less significant difference berween Dox and $A N-162$ was observed in the case of $\mathrm{H} 1299$ cells, which do not express sst. 5 . In Dox-sensitive H838 cells, both Dox and AN-162 showed significant proliferation inhibition at much lower concentrations. In vivo studies showed $-70 \%$ tumor growth inhibition on $\mathrm{H} 460$ xenografted nude mice, and $\sim 55 \%$ on H1299 xenografted ones. Upregulation of apoptotic genes by the treatment with AN-162 was also indicated. Similar results were obtained on tumor growth inhibition of the MDA-MB-231 estrogen-independent human breast cancer cell line xenografted into nude mice [66].

The treatment of hepatic cancer cells with a combination of two or three cytotoxic conjugates (AN-207 and AN-238 with 
c.

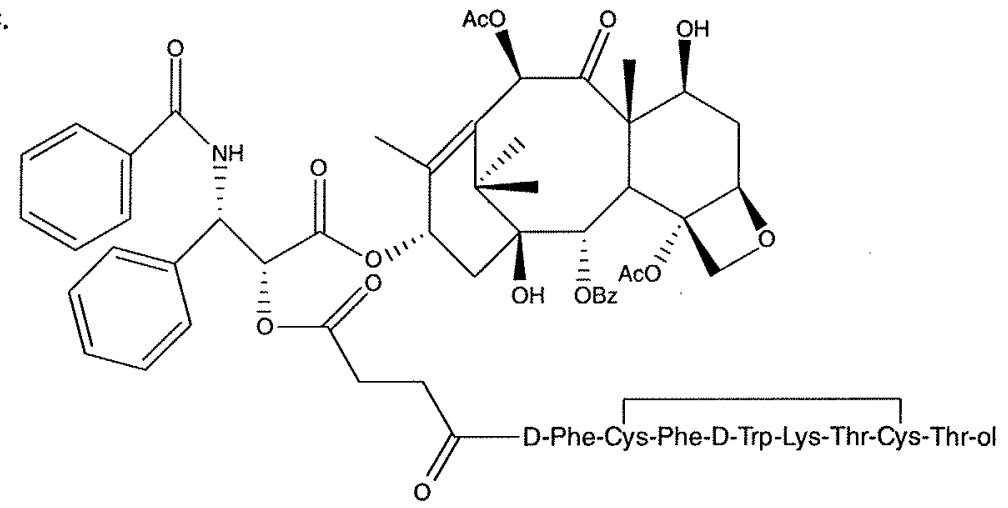

8 (PTX-OCT)

D.

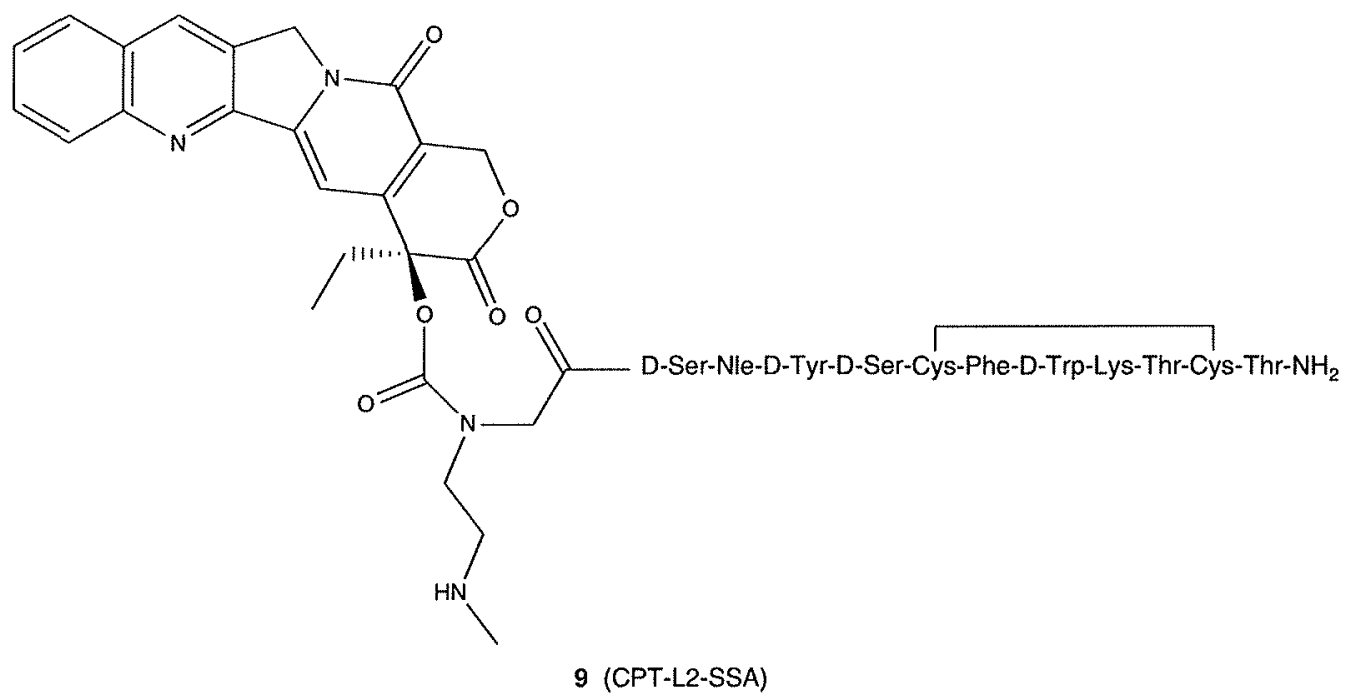

Figure 4. Chemical structures of cytotoxic somatostatin derivatives in which doxorubicin (A) and 2-pyrrolino-doxorubicin (B) were attached via ester bond to an octreotide analogue; ester bond-linked paclitaxel-octreotide (C) and carbamate containing camptothecin-somatostatin derivative conjugate (D). (Continued)

an extra bombesin-Dox conjugate; AN-215) resulted in higher in vitro tumor growth inhibition in comparision with their separate administration [32].

It has been shown that Paclitaxel (PTX) has high antitumor activity owing to its ability to promote tubulin assembly into microtubules, but it has a low cell specificity. Therefore, it was modified by succinic acid on its $2^{\prime}-\mathrm{OH}$ functional group and attached by means of an amide bond to the $\mathrm{N}$ terminus of octreotide [67]. This linkage allows the drug release by carboxylesterases, regenerating the free $2^{\prime}-\mathrm{OH}$, which appears essential for tubulin binding [68]. MCF-7 human breast cancer cell lines expressing $s_{1}{ }_{1}, s s t_{2}, s s t_{4}$ and $s s t_{5}$ but not $s s_{3}$, as well as $\mathrm{CHO}$ (Chinese hamster ovary) cells that have a very low level of somatostatin receptor $(196 \mathrm{fmol} / \mathrm{mg}$ ) were used to study the biological activity of the PTX-OCT (8) conjugate (Figure 4C). In the presence of PTX or PTX-OCT $\left(10^{-6}, 10^{-5}\right.$ and $\left.10^{-4} \mathrm{M}\right)$, the percentage of MCF-7 cells containing tubulin bundles was similar $(67,83$ and $92 \%$ or 65,81 and $93 \%$, respectively). However, on CHO cells, only PTX was significantly active. A large amount of octreotide could antagonize the cellular uptake of the conjugate but not of PTX, suggesting the difference between the cellular uptake mechanisms of the compounds (receptor-mediated versus passive diffusion). The viability of the MCF-7 cells incubated for $24 \mathrm{~h}$ with the conjugate or with the free PTX was similar ( $46 \pm 2.7$ and $41 \pm 3.3 \%$, respectively). These results indicate that PTXOCT conjugate is highly selective to the cells containing somatostatin receptors in comparision with the cells that express low levels of the receptors.

Recently, two PTX molecules were attached to the Lysmodified octreotide (2PTX-OCT) and the conjugate was tested on human NSCLC tumors $[69,70]$. Higher in vitro 
Table 2. In vivo and in vitro antitumor effect of AN-238 and other cytotoxic somatostatin derivative-conjugates.

\begin{tabular}{|c|c|c|c|c|}
\hline Tumor type & $\begin{array}{l}\text { Receptor expression } \\
\text { in specimens }\end{array}$ & $\begin{array}{l}\text { Cell types that } \\
\text { express SSTR }\end{array}$ & AN-238 & Others \\
\hline Breast & $\begin{array}{l}\text { sst2, sst5 } \\
\text { sst2, sst5 } \\
\text { sst2, sst5 } \\
\text { sst2a, sst4, sst1, sst5 }\end{array}$ & $\begin{array}{l}\text { MX-1 } \\
\text { MDA-MB-231 } \\
\text { MCF-7-MIII } \\
\text { MCF-7 }\end{array}$ & $\begin{array}{l}X X X X X^{*} \\
X X X \\
X X X \\
\text { n.d. }\end{array}$ & $\begin{array}{l}\text { XXXX (AN-162) } \\
\text { PTX-OCT PTX }\end{array}$ \\
\hline Ovarian & sst2a, sst 3 , sst 5 & $\begin{array}{l}\text { UCl-107 } \\
\text { OVCAR-3 } \\
\text { ES-2 }\end{array}$ & $\begin{array}{l}x X X \\
X X X \\
X X\end{array}$ & \\
\hline Endometrial & $\begin{array}{l}s s t 2 a, s s t 5 \\
s s t 2 a, s s t 5 \\
s s t 2 a, s s t 5\end{array}$ & $\begin{array}{l}\text { HEC-1A } \\
\text { RL-95-2 } \\
\text { AN3CA }\end{array}$ & $\begin{array}{l}x X x \\
X X X \\
X X X\end{array}$ & \\
\hline Prostate & $\begin{array}{l}s s t 2 a, s s t 5 \\
s s t 2 a, s s t 5 \\
s s t 2 a, s s t 5\end{array}$ & $\begin{array}{l}\text { MDA-PCa-2b } \\
\text { C4-2 } \\
\text { DU-145 } \\
\text { PC-3 } \\
\text { R-3327-AT-1 }\end{array}$ & $\begin{array}{l}X X X(P S A)^{\S} \\
X X X(P S A) \\
X X X X \\
X X X X \\
X X X X\end{array}$ & \\
\hline Colon & $\begin{array}{l}\text { sst2, sst5 } \\
\text { sst5 } \\
\text { sst2, sst5, sst3 }\end{array}$ & $\begin{array}{l}\text { HCT-15 } \\
\text { HT-29 } \\
\text { HCT-116 }\end{array}$ & $\begin{array}{l}X X X X \\
X X X X \\
X X X X\end{array}$ & . \\
\hline Renal & $\begin{array}{l}\text { sst2a } \\
\text { sst5 }\end{array}$ & $\begin{array}{l}\text { SW-839 } \\
786-0\end{array}$ & $\begin{array}{l}X X X \\
X X X X\end{array}$ & \\
\hline Melanoma & sst $1-$ sst 5 & $\begin{array}{l}\text { MRI-H255 } \\
\text { MRI-H187 }\end{array}$ & $\begin{array}{l}X X X \\
X X X\end{array}$ & \\
\hline Lung & $\begin{array}{l}\text { sst2, (sst5) } \\
\text { sst2a, (sst5) } \\
\text { sst5, sst3, sst1, (sst2) } \\
\text { (sst2a) } \\
\text { sst1, sst2a, sst3, (sst5) } \\
\text { sst2a, sst4, sst1, sst5 } \\
\text { sst2a, (sst5) } \\
\text { sst2 } \\
\text { sst2a, sst5, sst3, sst1 } \\
\text { sst2a, sst4, sst1, sst3 }\end{array}$ & $\begin{array}{l}\text { H838 (NSCLC) } \\
\text { H157 (NSCLC) } \\
\text { H727 } \\
\text { H720 } \\
\text { KRJ-1 } \\
\text { A549 (NSCLC) } \\
\text { H69 (SCLC) } \\
\text { H345 (SCLC) } \\
\text { H460 (NSCLC) } \\
\text { H1299 (NSCLC) }\end{array}$ & $\begin{array}{l}X X X \\
X X X X \\
\text { AN-238<AN-201 } \\
\text { AN-238<AN-201 } \\
\text { AN-238 = AN-201 } \\
\text { n.d. } \\
\text { XXX } \\
\text { AN-238<AN-201 } \\
\text { n.d. } \\
\text { n.d. }\end{array}$ & $\begin{array}{l}X X X(2 P t X-O C T) \\
\text { AN-162 <Dox } \\
\text { CPT-L1(L2)-SSA } \\
\text { AN-162 <DoX } \\
\text { CPT-L1(L2)-SSA } \\
\text { XXX (AN-162) } \\
\text { XXX (AN-162) }\end{array}$ \\
\hline Gastric & $\begin{array}{l}\text { sst2a, sst5, sst3 } \\
\text { sst2a, sst5, (sst3) } \\
\text { sst2a, sst5, (sst3 }\end{array}$ & $\begin{array}{l}\text { AGS } \\
\text { Hs 746T } \\
\text { NCl-N87 } \\
\text { MKN-45 }\end{array}$ & $\begin{array}{l}X X X \\
X X X X \\
X X X \\
A N-238<A N-201\end{array}$ & AN-162<Dox \\
\hline Pancreatic & $\begin{array}{l}\text { sst3, sst5 } \\
\text { sst3, (sst2), (sst5) } \\
\text { sst3, (sst2), (sst5) } \\
\text { sst3, sst2, (sst5) } \\
\text { sst2, sst5 } \\
\text { sst3, sst2, (sst5) }\end{array}$ & $\begin{array}{l}\text { SW-1990 } \\
\text { Panc-1 } \\
\text { Capan-1 } \\
\text { Capan-2 } \\
\text { CFPAC-1 } \\
\text { Mia-PaCa-2 }\end{array}$ & $\begin{array}{l}X X X X \\
X X X X \\
X X X X \\
X X X \\
X X X X \\
X X\end{array}$ & \\
\hline Non-Hodgkin's lymphoma & $\begin{array}{l}\text { sst } 1-s s t 5 \\
\text { sst } 1-s s t 5\end{array}$ & $\begin{array}{l}\text { RL } \\
\text { NL }\end{array}$ & $\begin{array}{l}X X X X \\
X X X X\end{array}$ & \\
\hline Hepatocellular & $\begin{array}{l}\text { sst2, sst } 3, \text { sst5 } \\
\text { sst2, sst3, sst5 } \\
\text { sst2, sst } 3, \text { sst5 }\end{array}$ & $\begin{array}{l}\text { SK-Hep-1 } \\
\text { HepG2 } \\
\text { Hep3B }\end{array}$ & $\begin{array}{l}X X X X \\
A N-238>A N-201 \\
A N-238>A N-201\end{array}$ & \\
\hline Brain & $\begin{array}{l}\text { sst2 } \\
\text { sst2 } \\
\text { sst2 }\end{array}$ & $\begin{array}{l}\text { IMR-32 neuroblastoma } \\
\text { U-118MG glioblastoma } \\
\text { U87-MG glioblastoma }\end{array}$ & $\begin{array}{l}\text { n.d. } \\
X X \\
X X X X X\end{array}$ & $\begin{array}{l}\text { CPT-L1(L2)-SSA } \\
<X X(A N-162)\end{array}$ \\
\hline
\end{tabular}

*In vivo studies: $X X X X X$ : regression; $X X X X:>70 \%$ inhibition; $X X X: 50-70 \%$ inhibition; $X X: 25-50 \%$ inhibition; n.d.: not determined.

${ }^{\ddagger} \mathrm{AN}-162>$ Dox represents the comparison of the in vitro antitumor effect of free drug and its GnRH derivative conjugate.

SPSA inh.: not the tumor volume, but PSA level was determined as a measure of the inhibitory effect.

CPT was more active than CPT-L1-S5A and CPT-L2-S5A.

The effects are not absolutely comparable because of different doses and treatment schedules used. 
and in vivo antitumor activity of 2PTX-OCT than that of PTX-OCT and free PTX was clearly demonstrated. Furthermore, its toxicity indicated by the white blood cell count was significantly lower than that of the free PTX. The antitumor effect of 2 PTX-OCT $(3 \times 150 \mathrm{nmol} / \mathrm{kg})$ resulted in the same inhibition on $\mathrm{H} 838$ xenografted nude mice $(60.7 \%)$ as observed by Schally's group using AN-238 ( 60\%) [64].

Fuselier et al. conjugated camptothecin as a cytotoxic agent to a somatostatin derivative D-Ser-Nle-D-Tyr-D-Ser-c(CysPhe-D-Trp-Lys-Thr-Cys)-Thr-NH $\mathrm{N}_{2}$. The N-terminal linking motif allowed the attachment of large groups without significant loss of receptor recognition of the cyclic somatostatin analogue [71]. CPT, which has antitumor activity by inhibiting the topoisomerase $I_{x}$ contains a hydroxyl group as a conjugation site, similarly to Dox and PTX. However, in this study a carbamate was applied as a linker because of its high stability in plasma compared with the commonly used ester-type linkage. The idea was that the cytotoxic agent should be masked until the internalization of the conjugate. Basic conditions or enzymatic attack result in the nucleophile-assisted release of the free camptothecin. Carbamates are metabolized by P450 enzyme that is upregulated in human cancer cells $[72,73]$. The half-life of the prepared compounds was between 18 and $106 \mathrm{~h}$ in rat serum, depending on the type of carbamate linker. The highest cytotoxic activity on human neuroblastoma IMR-32 cells was obtained in the case of CPT- $N$-methyl-aminoethyl-Gly-D-Ser-Nle-D-Tyr-D-Ser-c(CysPhe-D-Trp-Lys-Thr-Cys)-Thr-NH $\mathrm{NH}_{2}$ (CPT-L1-SSA) (9) (Figure 4D) $\left(\mathrm{IC}_{50}=54.2 \pm 6 \mathrm{nM}\right)$. Furthermore, the antitumor activity of the conjugate was evaluated on small cell lung cancer cells [74]. The conjugate bound to the NCL-H69 homogenate one order of magnitude better than its non-methylated version (CPT-aminoethyl-Gly-D-Ser-Nle-DTyr-D-Ser-c(Cys-Phe-D-Trp-Lys-Thr-Cys)-Thr-NH ${ }_{2}$ [CPTL2-SSA]). Significant in vitro cytotoxicity of the conjugate at $0.3-1 \mu \mathrm{M}$ concentration was obtained on $\mathrm{NCl}-\mathrm{H} 69$ and $\mathrm{NCI}-\mathrm{H} 345$ cell lines that have mRNA for sst $_{2}$ receptors.

CPT was also attached to the same somatostatin analogue via a cleavable carbamate group but using a different peptide linker sequence (D-Lys-D-Tyr-Lys-D-Tyr-D-Lys) 175]. This conjugate retained the potent biological activity and had comparatively low toxicity [76]. Its efficiency against PC-3 prostate cancer cell invasion was also demonstrated [77]. The CPT-somatostatin vector conjugate inhibited the expression of MMP-2 and MMP-9, but not the expression of MMP-3 and MMP-10 (MMP: matrix metalloproteinase) in PC-3 tumor cells. MMP-2 and MMP-9 have higher expression levels in tumor cells than in normal tissues and their expression correlates with the metastatic potential of the tumor cells [78]. CPT and the conjugate, but not the somatostatin analogue, inhibited the expression of $\alpha_{V} \beta_{3}$ and $\alpha_{V} \beta_{5}$ integrins at cell surfaces, tumor progression and metastasis, leading to the conclusion that CPT was responsible for this effect.

All these data show that the conjugation of CPT to somatostatin analogues increases the water solubility of
CPT, lowers the toxicity and increases the selectivity. The specific antitumor and antiangiogenic effects depend on the tumor cells that overexpressed somatostatin receptors.

\section{Somatostatin-based boron neutron capture therapy}

Boron neutron capture therapy (BNCT) is based on the nuclear capture and fission reactions that occur when non-radioactive ${ }^{10} \mathrm{~B}$ is irradiated with low energy $(0.025 \mathrm{eV})$ thermal neutrons to produce ${ }^{11} \mathrm{~B}$ in an unstable form, which undergoes instantaneous nuclear fission to produce $\alpha$-particles and recoiling ${ }^{7} \mathrm{Li}$ nuclei. These high linear energy transfer particles have a range of $5-9 \mu \mathrm{m}$, thereby restricting their destructive effects to only those cells containing ${ }^{10} \mathrm{~B}$. If ${ }^{10} \mathrm{~B}$ could be accumulated selectively in tumor tissues, which subsequently could be irradiated with thermal neutrons, the nuclear reaction products would specifically destroy the tumor DNA. The presence of $10^{9}(1.67 \times$ $10^{-15}$ mole) boron atoms per cell is generally required to achieve an antitumor effect. The target cells that efficiently bind the somatostatin conjugates contain several hundred femtomols $\left(-10^{-9}-10^{-10}\right.$ mole) of receptor per milligram membrane protein $\left(\sim 10^{7}\right.$ cells $)$ that might allow the uptake of the required amount of closo-boran cluster derivative for efficient BNCT. For this purpose, $\left[\mathrm{Tyr}^{3}\right]$-octreotate (D-Phe-c(Cys-Tyr-D-TrpLys-Thr-Cys)-Thr-OH) coupled with a borane cluster was prepared and functionally studied $[79,80]$. [ $\left.\mathrm{Tyr}^{3}\right]$-octreotate is an octreotide analogue with carboxyl group at the $\mathrm{C}$ terminus and Tyr in position 3 instead of Phe, which shows higher binding affinity and internalization rate $[5,81]$. A correlation was found between the binding affinity and the length of the inserted spacer between the borane cluster ( 10 boron atoms) and the octreotate 800 . However, the attachment of a higher number of closo-borane clusters ( 20 boron atoms altogether) in the conjugate had a negative influence on the affinity of the peptide. The binding affinity of the best compound (10) (Figure 5A) was $2-3 \mathrm{nM}\left(\mathrm{IC}_{50}\right)$ on $\mathrm{sst}_{2}$, but also some binding was observed on $s s t_{3}, s s t_{4}$ and $s_{4} t_{5}$ receptor subtypes. This range was similar to that observed in the case of radioligand-labeled somatostatin derivatives. Results of in vivo studies have not been published yet; however, the promising in vitro binding affinity of the conjugates to the somatostatin receptor-containing cells (Chinese hamster ovary carcinoma cells [CHO-K1] and Chinese hamster fibroblasts [CCL39]) may open a new direction for BNCT.

\section{Radiolabeled somatostatin derivatives}

Targeted radiotherapy of tumors overexpressing somatostatin receptors was shown to be a promising cancer therapeutic approach [5,9]. Although ${ }^{111}$ In-DTPA-octreotide (OctreoScan ${ }^{(B)}$, Mallinckrodt Medical) has become the most widely used tracer for somatostatin receptor scintigraphy [82,83], in the case of radiotherapy ${ }^{90} \mathrm{Y}$-DOTA-Tyr ${ }^{3}$-octreotide $\left({ }^{90}\right.$ Y-DOTATOC, 11$)$ (Figure $5 B$ ) has been the most frequently 
A.

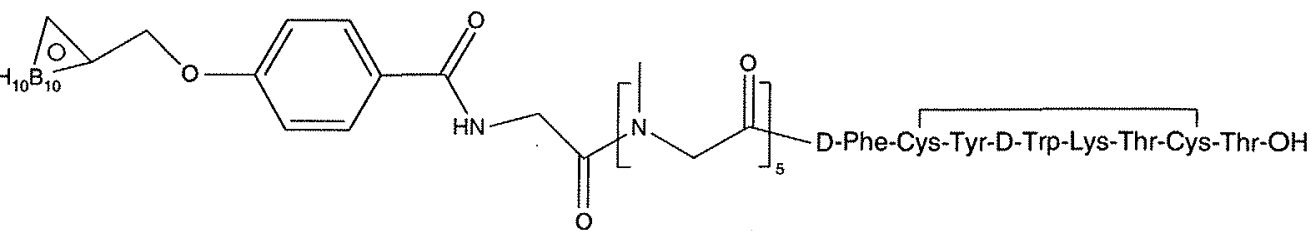

10

B.

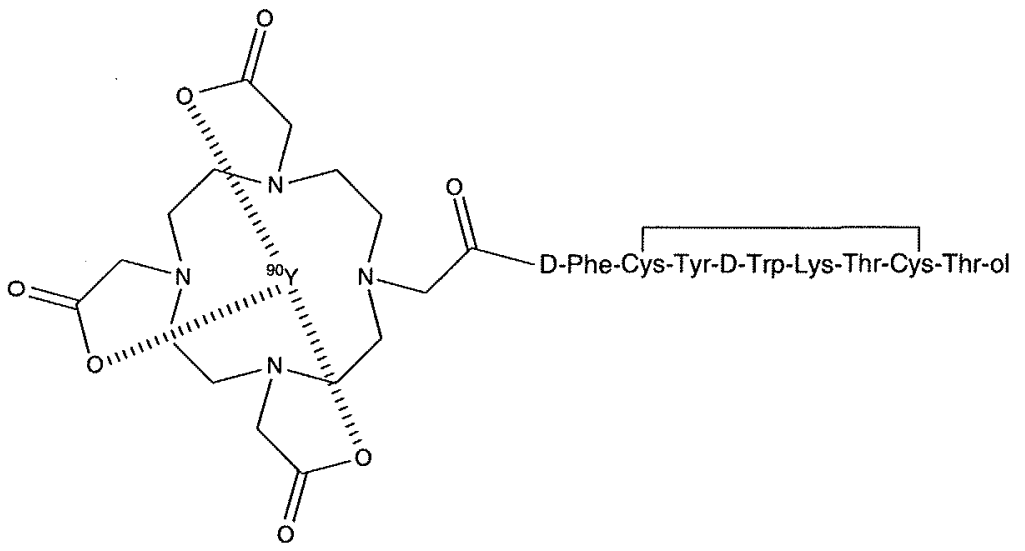

$11\left({ }^{90} \mathrm{Y}\right.$-DOTATOC)

c.

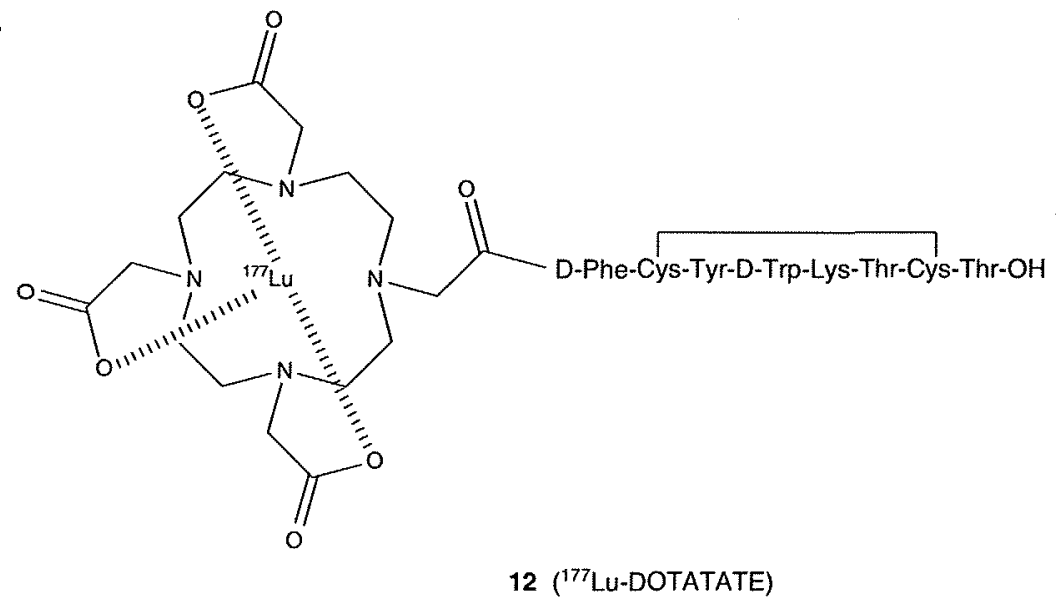

Figure 5. Chemical structures of a somatostatin conjugate for boron neutron capture therapy $(A)$ and of radiolabeled somatostatin derivatives: ${ }^{90} \mathrm{Y}$-DOTA-Tyr ${ }^{3}$-octreotide (B) and ${ }^{177}$ Lu-DOTA-Tyr ${ }^{3}$-octreotate (C).

used clinically for $>15$ years $[84,85]$. In the last decade, numerous compounds were developed in order to increase the receptor selectivity and/or bioactivity of the radiolabeled somatostatin derivatives. The modifications were carried out on the peptide sequence or by changing the radionuclides and/ or chelator. Insertion of $\mathrm{Ga}$ into DOTATOC markedly improved the $s_{2} t_{2}$ binding affinity and the in vivo tumor imaging [86-88]. Recent data also showed the high efficiency of ${ }^{y m^{m}}$ TC-EDDA/HYNIC-TOC for radioimaging (EDDA: ethylenediamine- $N, N^{\prime}$-diacetic acid, HYNIC: 6-hydrazinopyridine-3-carboxylic acid) [89-91]. The treatment of neuroendocrine gastroenteropancreatic tumors with ${ }^{177} \mathrm{Lu}$ DOTA-Tyr ${ }^{3}$-octreotate ( ${ }^{177}$ Lu-DOTATATE, 12)

(Figure $5 \mathrm{C}$ ), which had high affinity to sst $_{2}$, resulted in complete or partial tumor remission in $30 \%$ of patients in comparision with $10-30 \%$ in the case of ${ }^{90} \mathrm{Y}$-DOTATOC treatment [92]. ${ }^{177} \mathrm{Lu}$-DOTATATE also showed lower and mostly transient side effects (e.g., nephrotoxicity) and milder bone marrow supression than ${ }^{90}$ Y-DOTATOC. However, owing to the higher adsorbed dose but the lower tissue penetration range of ${ }^{177} \mathrm{Lu}$ than of ${ }^{90} \mathrm{Y}$, the ${ }^{177} \mathrm{Lu}$-DOTATATE may be more effective for smaller tumors. The combination of 
the two compounds might be also beneficial $[92,93]$. Incorporation of multiple DOTA chelators into the $\left[\mathrm{Tyr}^{3}\right]$ octreotate was described as a possible way to increase the efficacy [94]. Recently, it has been shown that the gemcitabine pretreatment upregulated the somatostatin receptor expression and acted as a radiosensitizer. The uptake of ${ }^{177} \mathrm{Lu}$-DOTATOC was $1.5-3$ times greater than that of untreated control cells [95]. Furthermore, the replacement of $\beta$-emitting ${ }^{177} \mathrm{Lu}\left(\mathrm{E}_{\max }=0.5 \mathrm{MeV}\right)$ in DOTATOC by $\alpha$-emitting ${ }^{213} \mathrm{Bi}\left(\mathrm{E}_{\max }=5.87 \mathrm{MeV}\right.$, half-life $\left.45.6 \mathrm{~min}\right)$ increased the effectivity 3.4 times [96]. The short-distance energy deposition of $\alpha$-ray $(-0.1 \mathrm{~mm})$ might be very active for inhibiting the tumor growth without side effects in the case of efficient tumor localization. Moreover, this high energy radiation depresses enzymatic DNA repair mechanisms.

The usefulness of somatostatin antagonists for tumor targeting has been demonstrated in the last few years. Somatostatin receptor-selective antagonists did not trigger receptor internalization, yet they were excellent tumor markers [97,98]. Antagonists are more hydrophobic and chemically more stable than agonists, resulting in longer duration of action and possible stabilization in the lipid-rich environment of the receptors. The strong receptor-ligand interaction and the slow internalization in the case of antagonists may provide a longer-lasting accumulation of the radioligand-labeled antagonist conjugate on tumor cells. A series of highly $s s t_{2-}$ selective somatostatin antagonists for radiotargeting were prepared [99]. The two most promising compounds were DOTA- $p \mathrm{NO}_{2}$ Phe-c[D-Cys-Tyr-D-Aph(Cbm)-Lys-Thr-Cys]D-Tyr-NH2 $\mathrm{NH}_{2}$ and DOTA-Cpa-clD-Cys-Aph(Hor)-D-Aph (Cbm)-Lys-Thr-Cys]-D-Tyr-NH $\mathrm{NH}_{2}$ (Cpa: 4-Cl-phenylalanine; Aph: 4-aminophenylalanine; Cbm: carbamoyl; Hor: L-hydroorotyl) with high binding affinities $\left(\mathrm{IC}_{50}<1 \mathrm{nM}\right)$. These results suggest that somatostatin antagonists as targeting moieties are suitable for radiotherapy.

\section{Conclusion}

Tumor targeting with hormone peprides provides a basis for the development of various cancer diagnostic and therapeutic approaches (targeted chemotherapy, targeted radiotherapy, photodynamic therapy and BNCT). The increased selectivity and decreased peripheral toxicity of such systems have already been demonstrated on different types of tumor. Moreover, increased solubility and bioavailability can be obtained by the application of these conjugates. Both somatostatin- and GnRH-containing conjugates are effective for targeting antineoplastic agents; however, the advantages of somatostatin analogues in targeted radiotherapy have been presented clearly. The first most active anticancer drug-peptide hormone conjugates are now in preclinical or clinical trials. However, it has to be taken into account that the side effects are mostly related to the low stability in serum of peptide drug conjugates, which leads to early drug release and consequently to 'nonspecific' toxicity. Furthermore, the presence of hormone receptors (especially somatostatin receptors) on normal cells might prevent the clinical application of some compounds. Therefore, the application of targeting moieties with increased specificity for the peptide receptors expressed on cancer cells and the application of linkers/spacers between the peptide and the drug that are stable in serum might improve the selectivity and efficacy of hormone-drug conjugates in targeted chemotherapy.

\section{Expert opinion}

Targeted chemotherapy represents a promising approach for the treatment of cancer. One possibility to enhance the selectivity and to decrease the peripheral toxicity of the well-known antineoplastic agents as well as radionuclides is the attachment to hormone peptides that bind to their receptors overexpressed on tumor cells. However, only a few of these hormone peptides ( $\mathrm{GnRH}$ and somatostatin) inhibit the tumor growth by receptor-mediated signal transduction pathway, the others stimulate the cell proliferation. Although the hormone peptide-drug conjugates are used at concentrations lower than the hormone dose required for tumor growth inhibition, the peptides with inhibitory effect should be preferentially used as targeting moieties for the preparation of drug delivery systems. Furthermore, the application of agonist derivatives instead of antagonists (preferred in the case of stimulatory peptides) might have a furcher benefit of faster receptor-ligand internalization. The internalization may be more important in the case of delivery of antineoplastic agents that have an intracellular site of action, whereas the intracellular delivery of radionuclides might not be necessary, especially in the case of $\beta$-emitters. However, the internalization of somatostatin agonist-bound radionuclids may lead to longer residence times of radionuclids in the tumor cells.

There are many promising data that confirm the efficiency of targeted therapy based on hormone peptides as targeting moieties. However, their receptors on cancer cells are limited, and their distribution on the cell surface might be heterogeneous. Futhermore, some receptors desensitize under continuous exposure to the hormone conjugate treatment. Research in the future should be focused on increasing the efficacy of the targeted therapeutic approaches. Several strategies to be pursued are the following.

(1) The combination of conjugates containing different targeting moieties. In this case different hormone receptors can be targeted. The same or different anticancer drugs can be attached to the selected hormone peptides. The latter combination might have the benefit that the drugs have different sites of action, resulting in high toxic effects on tumor cells.

(2) The development of conjugates in which two antineoplastic agents are coupled to a single hormone peptide. In this case, there should be an appropriate distance between the drugs and the targeting peptide in order to avoid the significant decrease of receptor binding affinity of the 
hormone. The number of drug molecules in a conjugate could be increased by the aid of multifunctional linkers.

(3) The combination of radionuclides and anticancer drugs in one conjugate or physical mixing of two different conjugates with the aim of combining radiotherapy and chemotherapy.

(4) The development of targeted nanoparticles containing encapsuled drugs by modifying their surface with hormone peptides.

It has been shown that the most efficient hormone-drug conjugates prepared so far have fairly low stability in serum. Therefore, the linkage and/or spacer between the components should be optimized further. The improvement of the serum stability of the conjugates as well as the efficient drug release might increase the therapeutic window and the efficacy of the drug targeting.

Further development of carriers, especially in the case of $\mathrm{GnRH}$, is required in order to prepare more potent compounds. Peptide derivatives with low endocrine but high antitumor activity are good candidates.
As intensive research is conducted in this field, more and more compounds as drug candidates might reach preclinical and clinical trials in the near future. Although in this review only GnRH- and somatostatin-based targeting approaches have been discussed in detail, other types of peptides as targeting moieties should be taken into account for further studies.

\section{Acknowledgments}

The authors thank $S$ Bajusz for critically reading the manuscript and for his advice.

\section{Declaration of interest}

The manuscript represents original work and has not been published previously or simultaneously submitted elsewhere for publication. The manuscript has been read and approved by both authors. The authors state no conflict of interest and have received no payment in preparation of this manuscript.

\section{Bibliography}

Papers of special note have been highlighted as either of interest $(\bullet)$ or of considerable interest $(\bullet \bullet)$ to readers.

1. World Health Organization (WHO). Available from: http://www.who.int/ cancer/en/, Fact sheet Nr. 297 , February 2009

2. Frei E III, Antman KH. Combination chemotherapy, dose, and schedule. In: Holland JR, Bast RC Jr, Morton DL, Frei E III, Kufe DW, Weichselbaum RR, editors, Cancer medicine. 4th Edition. Baltimore: Williams and Wilkins; 1997. p. 817-37

3. Schally AV, Nagy A. Chemotherapy targeted to cancers through tumoral hormone receptors.

Trends Endocrinol Metab 2004:15:300-10

4. Magrath T. Targeted approaches to cancer therapy. Int J Cancer 1994;56:163-6

5. Reubi JC. Peptide receptors as molecular targets for cancer diagnosis and therapy. Endocr Rev 2003;24:389-427

-. A comprehensive review of receptors of hormone/neurotransmitter peptides as molecular targets for cancer diagnosis and therapy.

6. Schally AV, Nagy A. Cancer chemotherapy based on targeting of cytotoxic peptide conjugates to their receptors on tumors. Eur J Endocrinol 1999;141:1-14
7. Moody TW, Mantey SA, Pradhan TK, et al. Development of high affinity camptothecin-bombesin conjugates that have targeted cytotoxicity for bombesin receptor-containing tumor cells. J Biol Chem 2004;279:23580-9

8. Moody TW, Sun L-CH, Mantey SA. In vitro and in vivo antitumor effects of cytotoxic camptothecin-bombesin conjugates are mediated by specific interaction with cellular bombesin receptors. J Pharm Exp Ther 2006;318:1265-72

9. Okarvi SM. Peptide based radiopharmaceuticals and cytotoxic conjugates: potential tools against cancer. Cancer Treat Rev 2008;34:13-26

- A comprehensive overview of peptide-based radiopharmaceuticals and cytotoxic conjugates, as well as their potential applications in cancer diagnosis and therapy.

10. Ulbrich $K$, Etrych $T$, Chytil $P$, et al. HPMA copolymers with $\mathrm{pH}$-controlled release of doxorubicin: in vitro cytotoxicity and in vivo antitumor activity. f Control Release 2003;87:33-47

11. Shiose $X$, Ochi $Y$, Kuga $H$, et al. Relationship between drug release of DE-310, macromolecular prodrug of DX-8951f, and cathepsins activity ins tumors. Biol Pharm Bull 2007;30:2365-70

12. Neill JD, Musgrove LC, Duck LW. Newly recognized GnRH receptors: function and relative role. Trends Endocrinol Metab 2004: $15: 383-92$

13. Shedgley $\mathrm{KR}$, Finch $\mathrm{AR}$, Caunt $\mathrm{CJ}$, McArdle CA. Intracellular gonadotropin-teleasing hormone receptors in breast cancer and gonadotrope lineage cells. J Endocrinol 2006;191:625-36

14. Millar RP, Lowe WN, ConkJin D, et al. A novel mammalian receptor for the evolutionarily conserved type II GnRH. Proc Nat Acad Sci USA 200 1;98:9636-41

15. Neill JD, Duck LW, Sellers JC, Musgrove LC. A gonadotropin-releasing hormone $(\mathrm{GnRH})$ receptor specific for GnRH-II in primates. Biochem Biophys Res Commun 2001;282:1012-8

16. Caunt CJ, Finch AR, Sedgley KR, et al Arrestin-mediated ERK activarion by gonadotropin-releasing hormone receptors: receptor-specific activation mechanisms and compartmentalization. J Biol Chem 2006;281:2701-10

17. Gründker $C$, Günthert $A R$, Millar RP, Emons $G$. Expression of gonadotropin-releasing hormone II (GnRH-H) receptor in human endometrial and ovarian cancer cells and effects of GnRH-Il on tumor cell proliferation. $\int$ Clin Endocrinol Metab 2002;87:1427-30

- Important data about the expression of GnRH-IIR on human cancer cells. 
18. Engel JB, Schally AV. Drug Insight: clinical use of agonists and antagonists of luteinizing-hormone-rcleasing hormone. Nat Clin Endocrinol Metab 2007;3:157-67

19. Gründker C, Schlotawa L, Vicreck V, et al. Antiproliferative effects of the $\mathrm{GnRH}$ antagonist cesrorelix and of GnRH-II on human endomerial and ovarian cancer cells are not mediated through the GnRH type I recepror. Eur J Endocrinol 2004;151:141-9

20. Fister $S$, Günthert AR, Emons $G$, Gründker $\mathrm{C}$. Gonadotropin-releasing hormone type II antagonists induce apoptoric cell death in human endometrial and ovarian cancer cells in vitro and in vivo. Cancer Res 2007;67:1750-6

21. Nagy A, Schally AV. Targeting of cytotoxic luteinizing hormone-releasing hormone analogs to breast, ovarian, endometrial, and prostate cancers. Biol Reprod 2005;73:851-9

-. A comprehensive overview of antitumor effect of doxorubicin-GnRH conjugates on different tumor types.

22. Keller G, Schally AV, Gaiser T, et al. Human malignant melanomas express receptors for luteinizing hormone releasing hormone allowing targeted therapy with cytotoxic luteinizing hormone releasing hormone analogue. Cancer Res 2005;65:5857-63

23. Keller G, Schally AV, Gaiser T, et al. Receptors for luteinizing hormone releasing hormone (LHRH) expressed in human non-Hodgkin's lymphomas can be targeted for therapy with cytotoxic LHRH analogue AN-207. Eur J Cancer 2005:41:2196-202

24. Nagy A, Schally AV. Cytotoxic analogs of luteinizing hormone-releasing hormone (LHRH): a new approach to targeted chemotherapy. Drugs Future 2002;27:359-70

25. Mezô G, Manea M, Szabó I, et al. New derivarives of $\mathrm{GnRH}$ as porential anticancer therapeutic agents. Curr Med Chem 2008;15:2366-79

26. Nagy A, Schally AV, Armatis P, et al. Cytoroxic analog luteinizing hormone-releasing hormone containing doxorubicin or 2-pyrrolinodoxorubicin, a derivative 500-1000 times more potent. Proc Natl Acad Sci USA 1996;93:7269-73

- $\quad$ First indication of the increased antitumor effect of 2-pyrrolinodoxorubicin and AN-207 conjugate (compared with doxorubicin and AN-152 conjugate).

27. Chatzistamou I, Schally AV, Nagy A, et al. Effective treatment of metastatic MDA-MB-435 human estrogen-independent breast carcinomas with a targeted cytotoxic analogue of luteinizing hormone-releasing hormone AN-207. Clin Cancer Res 2000;6:41 58-65

28. Schally AV. New approaches to the therapy of various tumors based on peptide analogues. Horm Metab Res 2008;40:315-22

29. Kovács M, Szepesházi K, Schally AV. Endocrine and antineoplastic effects of antagonistic and cytotoxic analogs of lureinising hormone-releasing hormone. In: Kovács $M$, Merchenhalter I, editors, Neuropeptides and peptide analogs. Research Signpost, Kerela, India; 2009. p. 33-57

30. Keller G, Schally AV, Gaiser T, et al Receptors for luteinizing hormone releasing hormone expressed on human renal cell carcinomas can be used for targeted chemotherapy with cytotoxic luteinizing hormone releasing hormone analogucs. Clin Cancer Res 2005;11:5549-57

31. Szepesházi K, Schally AV, Halmos G LH-RH receptors in human colorectal cancers: unexpected molecular targets for experimental therapy. Int $\mathrm{J}$ Oncol 2007;30:1485-92

32. Szepesházi K, Schally AV, Treszl A, et al. Therapy of experimental hepatic cancers with cytotoxic peptide analogs targeted to receptors for luteinizing hormone-relcasing hormone, somatostatin or bombesin. Anticancer Drugs 2008; 19:349-58

* First report on the possible benefits of combination therapy using different hormones as targeting moieties.

33. Günther, A, Gründker C, et al. Internalization of cytotoxic analog $A N-152$ of luteinizing hormone-releasing hormone induces apoprosis in human endomerrial and ovarian cancer cell lines independent of multidrug resistance-1 (MDR-1) system. Am J Obster Gynecol 2004;191:1164-72

34. Emons G, Sindermann H, Engel ], et al. Luteinizing hormone-releasing hormone receptor-targeted chemotherapy using AN-152. Ncuroendocrinol 2009;90:15-8
35. Nagy A, Plonowski A, Schally AV. Stability of cytotoxic luteinizing hormone-releasing hormone conjugatc (AN-152) containing doxorubicin-14-O-hemiglutarate in mouse and human serum in vitro: implications for the preclinical studies. Proc Narl Acad Sci USA 2000;97:829-34

36. Kovács $M$, Schally $A V$, Nagy $A$, et al. Recovery of piruitary function after treatment with a targeted cytotoxic analog of luteinizing hormone-releasing hormone. Proc Natl Acad Sci USA 1997;94:1420-5

37. Schally AV, Halmos G, Rékasi Z, Arencibia-Jimenez $] M$. The actions of LH-RH agonists and antagonists and cytotoxic analogs on the LH-RH receptors on the pituitary and tumors. In: P Devroey, editor, Infertility and reproductive medicine clinica of North America. Philadelphia: Saunders. $2001 ; 12: 17-44$

38. Sower SA, Chiang Y-C, Lovas S, Conlon JM. Primary structure and biological activity of a third gonadotropin-releasing hormone from lamprey brain. Endocrinol 1993;132:1125-31

39. Lovas $S$, Pályi 1, Vincze $B$, et al. Direct anticancer activity of gonadotropin-releasing hormone-III. J Pept Res 1998;52:384-9

40. Kovács $M$, Seprödi J, Koppán $M$, et al. Lamprey gonadotropin hormone-releasing hormone-III has no selective follicle-stimulating hormone-rcleasing effect in rats. J Neuroendocrinol $2002 ; 14: 1-14$

41. Szabó I, Manea M, Orbán E, et al. Development of an oxime bond containing daunorubicin-gonadotropin-releasing hormone-III conjugate as a potential anticancer drug. Bioconjug Chem 2009;20:656-65

- First data showing the in vivo antitumor activity of an oxime bond-linked daunorubicin-GnRH-III conjugate.

42. Kovács $\mathrm{M}$, Vincze $\mathrm{B}$, Horváth JE, Seprödi J. Structure-acrivicy study on the $\mathrm{LH}$ - and $\mathrm{FSH}$-releasing and anticancer effects of gonadotropin-releasing hormone (GnRH)-III analogs. Peprides 2007;28:821-9

- Important data regarding the selective antitumor activity of GnRH-III.

43. Sibrian-Vazquez $M$, Jensen TJ, Vicente $M G$. Synthesis, characterization, 
and merabolic stability of porphyrin-peptide conjugates bearing bifunctional signaling sequences J Med Chem 2008;51:2915-23

44. Bai KB, Láng $\mathrm{O}$, Orbán $\mathrm{E}$, er al. Design, synthesis, and in vitro activity of novel drug delivery systems containing tuftsin derivatives and methotrexate. Bioconjug Chem 2008;19:2260-9

45. Rahimipour S, Ben-Aroya N, Ziv K, et al. Receptor-mediated targeting of a photosensitizer by its conjugation to gonadotropin-releasing hormone analogues. J Med Chem 2003;46:3965-74

46. Dharap SS, Qui B, Williams GC, et al. Molecular targeting of drug delivery systems to ovarian cancer by $\mathrm{BH} 3$ and LHRH peptides. J Control Release 2003;91:61-73

47. Dharap SS, Wang $Y$, Chandna $P$, et al. Tumor-specific targeting of an anticancer drug delivery system by LHRH peptide. Proc Narl Acad Sci USA 2005;102:12962-7

48. Khandare J], Chandna $\mathrm{P}$, Wang $\mathrm{Y}$, et al. Novel polymeric prodrug with multivalent components for cancer therapy. J Pharm Exp Ther 2006;317:929-37

49. Chandna P, Saad M, Wang $Y$, et al. Targeted proapoptotic anticancer drug delivery system. Mol Pharm 2007;4:668-78

- $\quad$ First indication of a four-component drug delivery system containing $\mathrm{GnRH}$ as a targeting moiety.

50. Dharap SS, Minko T. Targeted proapoptotic LHRH-BH3 peptide. Pharm Res 2003;20:889-96

51. Barda $Y$, Cohen N, Lev V, et al. Backbone metal cyclization: novel $99 \mathrm{mTc}$ labeled GnRH analog as potential SPECT molecular imaging agent in cancer. Nud Med Biol 2004;31:921-33

52. Schorrelius M, Berger $S$, Poethko T, et al. Development of novel $68 \mathrm{Ga}$ - and $18 \mathrm{~F}-$ labeled GnRH-I analogues with high GnRH-targeting efficiency. Bioconjug Chem 2008;19:1256-68

53. Pawson AJ, Faccenda E, Maudsiey $S$, et al. Mammalian type I Gonadotropin-releasing hormone receptors undergo slow, constitutive, agonist-independent internalization. Endocrinology 2008;149:1415-22

54. Montagnani-Marelli $M$, Moretti RM, Januszkiewicz-Caulier J, et al.
Gonadotropin-releasing hormone $(\mathrm{GnRH})$ receptor sin tumors: a new rationale for the therapeutical application of $\mathrm{GnRH}$ analogs in cancer patients? Curr Cancer Drug Targets 2006;6:257-69

55. Bauer $W$, Briner $U$, Doepfner $W$, et al. SMS-201-995: a very potent and selective octapeptide analogue of somatostatin with prolonged action. Life $\mathrm{Sci}$ 1982;31:1133-40

56. Cai R-Z, Szőke B, Lu R, et al. Synthesis and biological acrivity of highly potent octapeptide analogs of somatostatin Proc Nat Acad Sci USA 1986;83:1896-900

57. Nagy A, Schally AV, Halmos G, et al. Synthesis and biological evaluation of cytotoxic analogs of somatostatin containing doxorubicin or its intensely potent derivative 2-pyrrolinodoxorubicin. Proc Natl Acad Sci USA 1998;95:1794-99

58. Schally AV, Comaru-Schally $M$, Nagy A, et al. Hypothalamic hormones and cancer. Front Neuroendocrinol 2001;22:248-91

59. Schally AV, Nagy A. New approaches to treatment of various cancers based on cytotoxic analogs of LHRH, somatostatin and bombesin. Life Sci 2003;72:2305-20

60. Engel JB, Schally AV, Halmos G, et al. Targeted therapy with a cytotoxic somatostatin analog, AN-238, inhibits growth of human experimental endometrial carcinomas expressing multidrug resistance protein MDR-I. Cancer 2005;104:1312-21

61. O'Byrne KJ, Schally AV, Thomas A, et al. Somatostatin, its receptors and analogs, in lung cancer. Chemotherapy 2001;47(S):78-108

62. Menda Y, Kahn D. Somatostatin receptor imaging of non-small cell lung cancerwith $99 \mathrm{~m}$ Tc depreotide. Semin Nucl Med 2002;32:92-6

63. Kiaris H, Schally AV, Nagy A, et al. A rargeted cytotoxic somatostatin (SST) analog, AN-238, inhibits the growth of H-69 small-cell lung carcinoma (SCLC) and $\mathrm{H}-157$ non-SCLC in nude mice. Eur J Cancer 2001;37:620-8

64. Szereday Z, Schally AV, Szepesházi K, et al. Effective treatment of $\mathrm{H} 838$ human non-small cell lung carcinoma with a targeted cytotoxic somatostatin analog, AN-238. Int J Oncol 2003;22:1141-6

65. Treszl A, Schally AV, Seitz $S$, et al. Inhibition of human non-small cell lung cancers wirh a targeted cytotoxic somatostatin analog, AN-162. Peptides $2009 ; 30: 1643-50$

66. Seitz S, Schally AV, Treszl A, et al. Preclinical evaluation of propertics of a new targeted cytotoxic somatostatin analog, AN-162 (AEZS-124), and its effects on tumor growth inhibition. Anticancer Drugs 2009;20:553-8

- First preclinical evaluation data of AN-162 conjugate on human breast cancer cells.

67. Huang C-M, Wu X-T, Chen S-T, Targeting delivery of paclitaxel into tumor cells via somatostatin receptor endocytosis. Chem Biol 2000;7:453-61

68. Nicolau KC, Dai WM, Guy RK. Chemistry and biology of taxol. Angew Chem Int Ed Engl 1994;33:15-44

69. Sun $M L$, Wei JM, Wang XW, et al. Paclitaxel-octreotide conjugates inhibit growth of human non-small lung cancer cells in vitro. Exp Oncol 2007;29:186-91

70. Shen H, Hu D, Du J, et al. Paclitaxel-octreotide conjugates in tumor growth inhibition of A549 human non-small cell lung cancer xenografted into nude mice. Eur J Pharmacol 2008;601:23-9

71. Fuselier JA, Sun L, Woltering SN, et al. An adjustable release rate linking strategy for cytotoxin-peptide conjugates. Bioorg Med Chem Lett 2003;13:799-803

72. Patterson LH, McKeowen SR, Robson T, et al. Antitumour prodrug development using cytochrome P450 (CYP) mediated activation. Anticancer Drug Des 1999;14:473-86

73. Cha SW, Gu HK, Lee KP, et al. Immunotoxicity of ethyl carbamate in female $\mathrm{BALB} / \mathrm{C}$ mice: role of esterase and cytochrome P450. Toxicology Lett 2000;1 15:173-81

74. Moody TW, Fuselier J, Coy DH, et al. Camprothecin-somatostatin conjugates inhibit the growth of small cell lung cancer cells. Peptides 2005;26:1560-6

75. Sun L-C, Fuselier JA, Coy DH. Effects of camprothecin conjugated to a somatostatin analog vector on growth of tumor cell lines in culture and related tumor sin rodents. Drug Deliv 2004; 11:231-8

- Application of a carbamate linker for the preparation of a somatostatin derivativecamptothecin conjugate. 
76. Bezerra Y, Fuselier JA, Peyma GA, et al. Study of inhibition effects o fan antiangiogenic somatostatin camtothecin conjugate on laser-induced choroidal neovascularization in rats. Retina 2005;25:345-54

77. Sun L-C, Luo J, Mackey LV, ct al. A conjugate of camptothecin and a somatostatin analog against prostate cancer cell invasion via a possible signaling pathway involving Pl3K/Akt, alphaVbeta3/alphaVbeta5 and MMP-2/-9. Cancer Lett 2007;246:157-66

78. John A, Tuszynszki $G$. The role of matrix metalloproteinases in tumor angiogenesis and tumor metastasis. Pathol Oncol Res 2001;7:14-23

79. Mier W, Gabel D, Haberkorn U, Eisenhut M. Conjugation of the closo-borane mercaptoundecahydrododecaborate (BSH) to a tumour selective peptide. Z Anorg Chem 2004;630:1258-62

80. Betzel T, Hess T, Waser B, et al. closo-Borane conjugated regulatory peptides retain high biological affinity: Synthesis of closo-borane conjugated Tyr3-octreotate derivatives for BNCT. Bioconjug Chem 2008;19:1796-802

- First indication of a hormone-borane conjugate as a potential therapeutic agent for BNCT.

81. de Jong $M$, Breeman WA, Bakker WH, et al. Comparison of (111) In-labeled somatostatin analogues for tumor scintigraphy and radionuclide therapy. Cancer Res 1998;58:437-41

82. Raderer $M$, Kurtaran A, Leimer $M$, et al. Value of peptide receptor scintigraphy using 123I-vasoactive intestinal peptide and $1111 \mathrm{n}$-DTPA-D-Phel-octreoride in 194 carcinoid patients: Vienna university experience, 1993-1998. J Clin Oncol 2000;18:1331-6

83. Rufini V, Calcagini ML, Baum RP. Imaging of neuroendocrine tumors. Semin Nud Med 2006;36:228-47

84. Kwekkeboom D, Krenning EP, de Jong $M$. Peptide receptor imaging and therapy. J Nucl Med 2000;41:1704-13

85. Bodei $L$, Cremonesi $M$, Zoboli $S$, et al Receptor-mediated radionuclide therapy with 90Y-DOTATOCin association with amino acid infusion; a phase 1 study. Eur J Nucl Med 2003;30:207-16

86. Reubi JC, Schaer JC, Waser B, et al. Affinity profiles for human somatostatin receptor sst 1 -sst 5 of somatostatin radiotracers selected for scintigraphic and radiotherapeutic use. Eur J Nucl Med $2000 ; 27: 273-82$

87. Henze M, Schumacher J, Hipp P, et al. PET imaging of somatostatin receptors using $[68 \mathrm{Ga}]$

DOTA-D-Phel-Tyr3-octrcotid: first results in patients with meningiomas. J Nucl Med 2001;42:1053-6

88. Koukouraki S, Strauss LG, Gcorgoulias V, et al. Evaluation of the pharmacokinetics of 68Ga-DOTATOC in patientswith metastatic neuroendocrine tumors scheduled for 90Y-DOTATOC therapy. Eur J Nucl Med Mol lmaging 2006;33:460-6

89. Storch $\mathrm{D}$, Béhé $\mathrm{M}$, Walter $\mathrm{MA}$, et al. Evaluation of [ $99 \mathrm{mTc} / \mathrm{EDDA} / \mathrm{HYNIC}$ ] octreotide derivatives compared with [111]n-DOTA0,Tyr3,Thr8]octreotid and [111n-DTPA0]octreotide: does tumor or pancreas uptake correlate with the rate of internalization? J Nucl Med 2005;46:1561-9

90. Gambini JP, López Lerena J], Quagliata A, et al. 99mTc-HYNIC octreotide in neuroblastoma. Ann Nud Med 2008;22:817-9

91. Chen L, Li F, Zhuang $\mathrm{H}$, et al. $99 \mathrm{~m}$ Tc-HYNIC-TOC scintigraphy is superior to $1311-\mathrm{MIBG}$ imaging in the evaluation of extraadrenal pheochromocyroma. J Nud Med 2009;50:397-400

92. Kwekkeboom Df, Mueller-Brand J Paganelli $G$, et al. Overview of results of peptide receptor radionuclide therapy with 3 radiolabeled somatostatin analogs. I Nud Med 2005;465:62-6

93. De jong $M$, Valkema $R$, Jamar $F$, et al Somatostatin recepror-targeted radionuclide therapy of tumors: preclinical and clinical findings. Semin Nucl Med 2002;32:133-40

94. Mier W, Graham KAN, Wang Q, et al. Synthesis of peptide conjugated chelator oligomers for endoradiotherapy and MRT imaging. Tetrahedron Lett 2004; $45: 5453-5$
95. Nayak TK, Atcher RW, Prossnitz ER, Norenberg JP. Enhancement of somatostatin-receptor-targeted 177Lu-[DOTA0-Tyr3]-octreotide therapy by gemcitabine prtreatment-mediated receptor uptake, up-regulation and cell cycle modulation. Nud Med Biol 2008;35:673-8

96. Nayak TK, Norenberg JP, Anderson TL, ct al. Somatostatin-rcceptor-targeted a-cmitting $213 \mathrm{Bi}$ is therapeutically more effective than bet $\bar{a}-\mathrm{cm} i t t i n g ~ 177 \mathrm{Lu}$ in human pancreatic adenocarcinoma cells. Nucl Med Biol 2007;34:185-93

97. Ginj $M$, Zhang $H$, Waser $B$, et al. Radiolabeled somatostatin receptor antagonists are preferable to agonists for in vivo peptide receptor targeting of tumors. Proc Natl Acad Sci USA 2006;103:16436-41

98. Cescato R, Schulz $S$, Waser B, et al. Internalization of sst2, sst3, and sst 5 receptors: effects of somatostatin agonists and antagonists. J Nucl Med 2006;47:502-11

- Important data on somatostatí antagonist derivatives and their potential tumor-targeting applications.

99. Cescato R, Erchegyi J, Waser B, et al. Design and in vitro characterization of highly sst2-selective somatostatin antagonists suitable for radiotargeting. J Med Chem 2008;51:4030-7

\section{Affliation}

Gábor Mezón $^{\text {t1 }}$ \& Marilena Manea ${ }^{2,3}$

${ }^{\dagger}$ Author for correspondence

${ }^{1}$ Eötvös Loránd University,

Research Group of Peptide Chemistry,

Hungarian Academy of Sciences,

1117 Budapest, Pázmány P. stny. 1/A,

Hungary

Tel: $+3613722500 / 1433$; Fax: +361372 2620;

E-mail; gmezo@elte.hu

${ }^{2}$ University of Konstanz,

Department of Chemistry,

Laboratory of Analytical Chemistry and

Biopolymer Structure Analysis,

78457 Konstanz,

Germany

${ }^{3}$ University of Konstanz

Zukunftskolleg, 78457 Konstanz,

Germany 